\title{
COMMUNICATING A CULTURE OF PEACE IN AOTEAROA NEW ZEALAND: THE VISION OF PEACE THROUGH UNITY
}

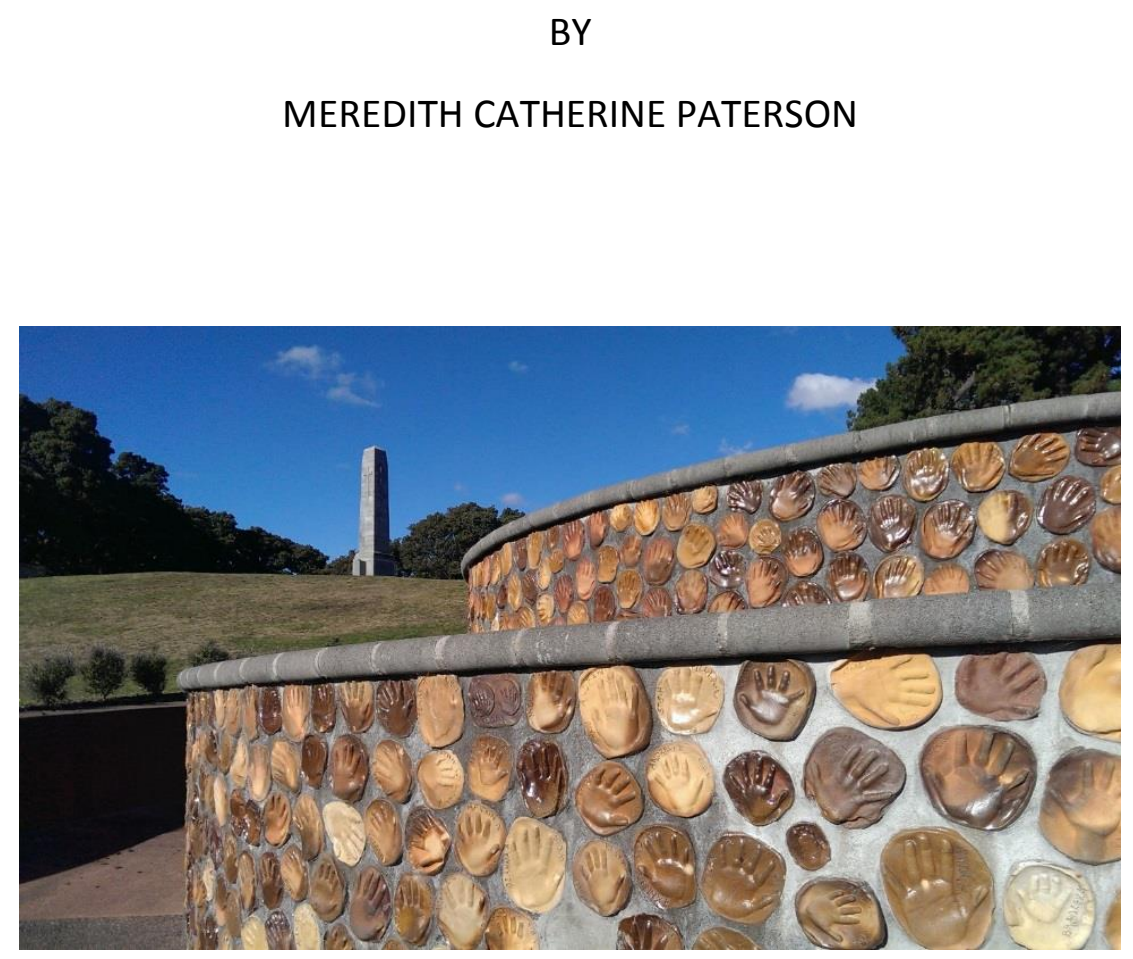

INTP595 Research Topic in International Relations

\begin{abstract}
A thesis
submitted to the Victoria University of Wellington

in partial fulfilment of the requirements for the degree of

Master of International Relations
\end{abstract}

Victoria University of Wellington 


\section{Acronyms}

$\begin{array}{ll}\text { CAMDUN } & \text { Campaign for a More Democratic United Nations } \\ \text { CONGO } & \text { Conference of Non-governmental Organizations in Consultative Relationship with the } \\ \text { UN } & \text { Committee on Spirituality, Values and Global Concerns } \\ \text { ECOSOC } & \text { Economic and Social Council } \\ \text { GMCOP } & \text { Global Movement for a Culture of Peace } \\ \text { GJNs } & \text { Global Justice Networks } \\ \text { MTM } & \text { Many to Many } \\ \text { NGO } & \text { non-governmental organization } \\ \text { OPTU/PTU } & \text { Operation Peace through Unity/ Peace through Unity } \\ \text { SDGs } & \text { Sustainable Development Goals } \\ \text { UN } & \text { United Nations } \\ \text { UNDPI } & \text { United Nations Department of Public Information } \\ \text { UNESCO } & \text { United Nations Educational, Scientific and Cultural Organization } \\ \text { WDC } & \text { Whanganui District Council } \\ \text { WCC } & \text { Wellington City Council }\end{array}$




\begin{abstract}
Narrative politics reframes how we cultivate knowledge in the academy, foregrounding the voices of research subjects and their relationships with researchers to re-embed scholars in the social world. Narrative affects the reader's emotional capacities and fosters empathic understanding, encouraging a more human engagement with figures that have been made threatening, as Elizabeth Dauphinée explores in The Politics of Exile and Richard Jackson in Confessions of a Terrorist. Narrative politics is concerned with the question of how academics respond to the violence of war and whether the analytical tools of the social sciences are an adequate response to the human horror of war.
\end{abstract}

The narratives of peace people are particularly compelling in the way they challenge the assertions of the dominant culture of wider society and the discipline of IR. Aotearoa New Zealand has a rich history of grassroots peace movements and activities that have influenced wider society. However, their stories are not well recorded in the dominant narrative of state institutions or academia. Peace Activist Elsie Locke published Peace People, a broad historical survey of peace activism from pre-European Maori to 1975. Maire Leadbeater brings the account up to 2013 in Peace, Power and Politics. All accounts emphasise that ordinary people were at the heart of activities, organisations and movements for peace.

One of these 'ordinary' people left out of Locke and Leadbeater's accounts is Gita Brooke, cofounder of the Whanganui-based charitable trust, Peace through Unity [PTU]. As a self-identified 'peace person,' Brooke has written much about their work and been involved in peace activities in Aotearoa NZ since the 1980s. Narrative politics provides a lens in IR to explore the story of Gita Brooke as co-founder of PTU. I show the contribution PTU has made and continues to make to a culture of peace in Aotearoa New Zealand and as a worldwide network, explored through the themes of education for global citizenship, transformation through thought-work, and responsibility for local action. It examines how PTU's vision of a culture of peace has been communicated through the organisation's newsletter, Many to Many, through its involvement with the United Nations as an accredited NGO, and through its local activities. Using archival sources, data from interviews and a content analysis of the newsletter, and complemented by the lens of and insights from the discourse of narrative politics, this study suggests that PTU provides a space for critical self-reflection in the pursuit of peace that challenges the thought/action binary of institutionalised NGOs. The deterritorialised publication, Many to Many, connects peace people through a networked area of mutual agreement that is inclusive, educative and transformative. 


\section{Contents}

Acknowledgements $\quad 5$

$\begin{array}{ll}\text { Preface: conversations with a visionary as narrative politics } & 6\end{array}$

$\begin{array}{ll}\text { Chapter 1: Introduction } & 11\end{array}$

i. The vision of Peace through Unity

ii. Defining a culture of peace

iii. Context and background to Peace through Unity and newsletter Many to Many

iv. Identifying and foreshadowing central themes

$\begin{array}{ll}\text { Chapter 2: Education } & 25\end{array}$

i. Many educating many: an area of mutual agreement in print

ii. Peace education as the promotion of Unity

iii. Education as worldview transformation

Chapter 3: Transformation

i. The spiritual underpinnings of PTU's vision

ii. Grounding the seven points of 'Towards Peace Through Unity'

iii. The political implications of spirituality for the 'ordinary citizen'

Chapter 4: Responsibility

i. Taking responsibility: responding to calls to action

ii. Limitations to acting as global citizens

iii. Local days of action: the Handspan Sculpture, Whanganui, and the International Day of Peace, Wellington 2015

i. Extending the brief of narrative politics in International Relations

ii. Future directions for research

Bibliography 


\section{Acknowledgments}

Tremendous thanks to Dr Sydney Shep and Dr Kate Schick for their encouragement, support and guidance.

Love and thanks to my family and friends. Thanks to Diane Paterson, Hayley Heyes, Cassandra Burton-Wood and Louisa Hormann for the encouraging and thought-provoking conversations. Much love to Dylan Sofa.

My thanks and gratitude to Kate Smith, Iris Spellings and Steve Nation for supporting and being part of this project, and to PTU co-workers everywhere for their ongoing work for peace.

And of course, thank you Gita for opening your heart, house and archive to me.

For Gita and Anthony Brooke. 


\section{Preface: conversations with a visionary as narrative politics}

Sometimes we hear the narrative of an individual that undoes what we think we know of the world. Their story captures what our theory cannot explain, affects us in a way argument cannot. This moment contains potential for a change in thinking, a reorientation to the teller, the other. Or, it may be forgotten, it may be shrugged aside. Narrative is a tool for knowing and telling, absorbing and expressing knowledge. It has been defined as the principle tool we have as humans to order and understand time. But it also has the potential to disrupt time, to represent it in non-linear ways more representative of traumatic experiences, such as war. Some narratives serve a similar function to theory - to simplify and order a complex world. Most theories tell us stories about the way the world is. The discipline of International Relations (IR) is already involved in telling stories about itself epitomised by the arc of disciplinary formation taught as the Great Debates. ${ }^{1}$ IR uses mainstream theory to simplify and order a complex world. Academics observe a pattern in society, make a generalization, and then analyse case studies to show they understand. Everything is explainable. Even the motivations of war criminals, dictators and soldiers can be known. We look at structure, we look at agency. The rigorous norms of academic objectivity and formal writing are put to work. These are useful analytical tools. But what is lost in the telling? Is there another way of knowing our subject? Can narrative capture complexity and affect the reader in ways academic articles cannot?

Narrative politics is critical, post-positivist approach that disrupts and critiques mainstream approaches to IR. It offers different ways of knowing and judging that introduce uncertainty and vulnerability through the questioning of form and voice in academic writing. Elizabeth Dauphinée, editor of the Journal of Narrative Politics, critiques academic writing as an output of a certain kind of defensive scholarship across the social sciences. She argues that the "contours of academic debate" are structured in an "adversarial way," like a battle, that is reflective of the discipline itself. ${ }^{2}$ Dauphinée saw her students protecting themselves from attack by choosing safe, small ideas reliant on established theorists and scholars. ${ }^{3}$ Few were brave enough to try their own ideas. Defensive scholarship inhibits the creation and cultivation of new knowledge and reduces the impact the writing can have on the

\footnotetext{
${ }^{1}$ Elizabeth Dauphinee, "The Ethics of Autoethnography," Review of International Studies 36, no. 3 (July 2010): 807, doi:http://dx.doi.org.helicon.vuw.ac.nz/10.1017/\$0260210510000690.

${ }^{2}$ Ibid., 804.

${ }^{3} \mathrm{Ibid}$.
} 
reader, who like the student defends themselves from attack rather than opens to listen and think differently.

Narrative politics challenges the voice in which academics write. Roxanne Doty critiques the dispassionate academic voice as making academics into, "hideous beings swallowed up by our scholarly clothes, the dancing fools under the fluorescent lights of our paradigms and theories that voraciously consume our thoughts, hammer the soul from our words, and drain our voices of any traces of humanity." ${ }^{4}$ The personal voices of academics are masked and silenced by the voice they use to gain legitimacy in the discipline of IR.

Further, the rationalist mode of intellectual pursuit expects academics to speak from what Kimberly Hutchings describes as a no-place of reason, a place that insulates them from the social world of which they write. ${ }^{5}$ The abstraction from the social world makes one safe from injury but unable to speak of history, emotion and community, key aspects of the human experience that make us vulnerable, as discussed by Beattie and Schick in The Vulnerable Subject. ${ }^{6}$

Narrative politics thus draws on ethnographic, feminist and post-colonial modes of research that are more inclusive of these aspects of human life as a wellspring of learning, situate the writer in their craft and allow them to speak with their own voice. Feminist theorist Carol Cohn was a forerunner in her analysis of the technostrategic discourse of defence intellectuals, drawing on personal experience and narratives throughout the artcicle. ${ }^{7}$ Morgan Brigg and Roland Bleiker argue for the validity of auto-ethnography in IR, exploring the self as a source of knowledge, as does Oded Löwenheim. ${ }^{8}$ Himadeep Muppidi explores how narratives can "exile us from an IR scholarship trapped in an economy of colonial truth," and explores the ethical relations of responsibility that can then

\footnotetext{
${ }^{4}$ Roxanne Lynn Doty, "Maladies of Our Souls: Identity and Voice in the Writing of Academic International Relations," Cambridge Review of International Affairs 17, no. 2 (July 1, 2004): 378, doi:10.1080/0955757042000245951.

${ }^{5}$ Kimberly Hutchings, "A Place of Greater Safety? Securing Judgement in International Ethics," in The Vulnerable Subject, ed. Kate Schick and Amanda Russell Beattie (United Kingdom: Palgrave Macmillan, 2013), 25-42.

${ }^{6}$ Amanda Russell Beattie and Kate Schick, The Vulnerable Subject: Beyond Rationalism in International Relations (Palgrave Macmillan, 2012).

${ }^{7}$ Carol Cohn, "Sex and Death in the Rational World of Defense Intellectuals," Signs 12, no. 4 (July 1, 1987): 687718.

${ }^{8}$ Morgan Brigg and Roland Bleiker, "Autoethnographic International Relations: Exploring the Self as a Source of Knowledge," Review of International Studies 36, no. 3 (July 2010): 779-98, doi:http://dx.doi.org.helicon.vuw.ac.nz/10.1017/S0260210510000689; Oded Lowenheim, "The 'I' in IR: An Autoethnographic Account," Review of International Studies 36, no. 4 (October 2010): 1023-45, doi:http://dx.doi.org.helicon.vuw.ac.nz/10.1017/S0260210510000562.
} 
emerge. ${ }^{9}$ Shilliam reconnects the narratives of peoples segregated by the 'cutting logic' of colonisation. ${ }^{10}$ While not all relaying on purely narrative form, these scholars show there are powerful alternative and innovative ways to write and to know our subjects in IR.

Narrative politics reframes how we cultivate knowledge in the academy, foregrounding the voices of research subjects and their relationships with researchers to re-embed scholars in the social world. Elizabeth Dauphinée re-examined her field of expertise, the Bosnian War, in The Politics of Exile, written in purely narrative form, through the relationship of an academic with a putative war criminal. ${ }^{11}$ Narratives such as Dauphinée's The Politics of Exile, re-embed the academic in these facets of human experience as it enables them to speak of their relationships with other humans. The humanizing effect of narrative is realized by Richard Jackson in his novel, The Confessions of a Terrorist. ${ }^{12}$ Jackson breaks the taboo of allowing the terrorist to speak as a fellow human being in order to better understand and relate to what would drive someone to violent action. He suggests that the fear that we might relate to what has been made inhuman, the terrorist, is what causes dehumanisation and exclusion in most public forums. ${ }^{13}$ Richard Jackson suggests narrative can have a lasting impact on the reader through affect and emotion, rather than confrontation. ${ }^{14}$ Narrative affects the reader's emotional capacities and fosters empathic understanding, encouraging a more human engagement with what has been made threatening, such as a war criminal or terrorist. Uncertainty can thus be introduced in the readers mind, allowing them to critically examine the humanity of those represented in regards to their own. There is a strong connection between the ability to speak as and for oneself, and the recognition of being human.

A narrative approach to the discipline of International Relations is gaining traction, spurred by confronting panel discussions at international conferences that made space for researchers to share their personal stories. Growing from these conversations, the Journal of Narrative Politics was established "to explore the overlaps between aesthetics, politics, theory and ethics." ${ }^{15}$ The Journal is

\footnotetext{
9 Himadeep Muppidi, “On The Politics of Exile,” Security Dialogue 44, no. 4 (August 1, 2013): 299, doi:10.1177/0967010613493457.

${ }^{10}$ Robbie Shilliam, The Black Pacific: Anti-Colonial Struggles and Oceanic Connections (London: Bloomsbury, 2015).

${ }^{11}$ Elizabeth Dauphinée, The Politics of Exile (New York, NY: Routledge, 2013).

12 Richard Jackson, Confessions of a Terrorist (London: Zed Books Ltd, 2014).

13 Ibid.

${ }^{14}$ Richard Jackson, "Terrorism, Taboo, and Discursive Resistance: The Agonistic Potential of the Terrorism Novel," International Studies Review 17, no. 3 (September 1, 2015): 400, doi:10.1111/misr.12227.

15 “About the Journal," Journal of Narrative Politics, 2016, http://journalofnarrativepolitics.com/.
} 
"less concerned with the analysis of narrative" and more "with narrative itself as a mode of knowing."16 The Journal has made space for academics as authors to reflect on formative personal relationships and experiences they have had during the course of research. It also makes space for academics to reflect on personal reasons for what they study and childhood experiences that have shaped their adult lives. It allows them to situate themselves in their work. Many of the narratives are set in contexts of war or refuges from the devastation of war. ${ }^{17}$ Narrative politics is concerned with the question of how academics respond to the violence of war and whether the analytical tools of the social sciences are an adequate response to the human horror of war. ${ }^{18}$ The experiences and relationships described are vital to the research process, and yet they cannot be shared in the final product due to the conventions of academic writing.

The narratives of peace people are particularly compelling in the way they challenge the assertions of the dominant culture of wider society and the discipline of IR. In what follows, I focus on the narrative of Gita Brooke, co-founder of Peace through Unity. I met Gita Brooke in my final year of high school through a friend who knew I was interested in peace and social justice. After I moved to Wellington to study at Victoria I continued to visit Gita for cups of tea and conversation when I went home to Whanganui. Her wisdom and dynamism impressed me, as did the incredible stories of her life and travels. She told me about a culture of peace and shared the vision of Peace through Unity. I'd come away feeling thoughtful and encouraged, often with the latest issue of Many to Many in hand. Gita embodies a culture of peace, and her house embodies her spirit. It is a restful place full of a feeling of peace. It is also the archive of writings, objects, artworks, photographs, posters and poems of the lives of Gita and her late husband, Anthony Brooke. Lately, Gita has been thinking about the legacy of Peace through Unity and her house, called Rumah Brooke or Te Rangi/the Sky. I wanted to draw the vision of PTU in the academy as part of this legacy for future peace researchers. Learning about PTU and the Brookes is learning about a culture of peace, the advocates of which are often unknown and pass unrecorded. With the support of my supervisors, I have attempted to address this through the following thesis. Narrative politics provides a lens in IR to tell the story of Gita Brooke as part of PTU.

\footnotetext{
16 Ibid.

${ }^{17}$ For an example of all three of the above aspects see Sorayya Khan, "The Silence and Forgetting That Wrote NOOR," Journal of Narrative Politics 1, no. 2 (March 2015): 121-32.

${ }^{18}$ As explored in Elizabeth Dauphinée, The Ethics of Researching War: Looking for Bosnia, 1 edition

(Manchester; New York; New York: Manchester University Press, 2007).
} 
I have a drawn a connection between the concerns of narrative politics and my own concern for the remembrance of the narratives of peace people, such as Gita Brooke. Our relationship provided the access point for this project. Our conversations were the starting point of this ongoing learning process. In the process of researching and writing, I have better recognized my own limitations as skills to be developed or as pressures from the university. I have attempted to include the voice of Gita Brooke and her co-workers who have contributed to the impressive corpus of Many to Many alongside scholars in an interdependent project of knowledge cultivation on a culture of peace. My efforts are incomplete in the face of this challenging and ongoing work. The concerns of narrative politics as an approach to scholarship became clearer in the process of researching, particularly the difficulty of making academic writing accessible to those without the training of specific disciplines. My task as a researcher was not to reproduce the PTU perspective verbatim, but to interrogate its significance to IR. For an organisation whose approach has always been not to take credit for things but work anonymously behind the scenes, it is challenging to be given credit and made visible through a researcher's words. I am extremely grateful to Gita, Peace through Unity and my supervisors for enabling me to venture into new territory. 


\section{Chapter 1: Introduction}

\section{The vision: 'Towards Peace through Unity'}

In 1975, Gita and Anthony Brooke cofounded charitable trust, Peace through Unity (PTU), in Sweden which is now based in Whanganui, Aotearoa New Zealand (NZ). ${ }^{19}$ Gita was living in Sweden at that time and Anthony was travelling on a speaking tour throughout Europe. Soon after the formation of PTU, Gita joined Anthony on his tour for what developed into continuous travel for ten years (1978-1988), during which they shared the vision of peace through unity around the world. ${ }^{20}$ Together, they wrote their vision for peace in the pamphlet, 'Towards Peace through Unity. ${ }^{21}$ This vision formed the basis of PTU's work for a culture of peace, during their travels and when they settled in Whanganui (1988 present). It outlines their method of working as an unconventional non-governmental organization (NGO) that operates as a network, trusting the goodwill and service of people everywhere. It introduces the spiritual underpinnings of PTU and offers seven points that might provide the bases of mutual understanding. Latter publications, including PTU's newsletter Many to Many (MTM) grew from the convictions expressed in this pamphlet.

The pamphlet describes the when or context of PTU, who it interpolates as readers and coworkers, and how it suggests they act differently to build more peaceful relationships. PTU's vision frames the context as a "time of unprecedented change and transformation." It speaks to the powerful efforts of the "ordinary citizen of goodwill," and suggests the creation of an "area of mutual agreement," in which to develop cooperative relationships. As the name suggests, the vision is through unity, peace, as achieved through 'right relationships' with all living things. It describes a way of living that strives for the best one can be in accordance with ideal values: cooperation, respect and unity.

The focus of PTU has been to promote and nurture a culture of peace. Visions of how the world could be are vitally important for creating cultures of peace. As Director for the National Centre for

\footnotetext{
${ }^{19}$ Peace through Unity (PTU) refers is registered as a Charitable Trust and accredited NGO to the UN DPI under this name. However, the Brookes changed the name to Operation Peace through Unity (OPTU) in common usage. Both refer to the same organization. For the purposes of this thesis, the legal name (PTU) is used. ${ }^{20}$ Anthony Brooke, "Anthony's Story Continued, 1970-Present," Operation Peace through Unity, accessed January 12, 2016, http://www.peacethroughunity.info/background-anthonystory8.html\#here; Gita Brooke, Interview 1, August 24, 2015.

${ }^{21}$ Gita Brooke, "Towards Peace Through Unity" (Peace Through Unity, 1975), http://www.peacethroughunity.info/archives_1975pam.html.
} 
Peace and Conflict Studies at Otago University, Kevin Clements, ${ }^{22}$ says, "peace cultures thrive on and are nourished by visions of how things might be." ${ }^{23}$ The importance of peace visionaries to the academy is made clear by Clements when he says, "It is vital that researchers and practitioners identify and politically locate those who are articulating particular visions of peace from a range of culture and gender perspectives." ${ }^{24}$ However, peace workers and visionaries are hard to see through the dominant lenses of International Relations, which tend to focus on the state or political institutions rather than the individual. Clements points out that, "The independent role of community and civil society networks in determining stable peace is relatively under-theorized and needs to be given greater attention." ${ }^{25}$ Here, Clements is speaking in the context of post-conflict situations or zones of peace building projects, but it is equally true for the context of Aotearoa NZ.

Visionaries and peace practitioners in Aotearoa are not well remembered in the public sphere, nor are their stories well recorded. There is a significant risk that we will lose the vital visions for a more peaceful Aotearoa NZ, and world, and the practical effects that vision might lead to. Dick Scott, author of Ask that Mountain, highlights how the story of a seminal peace movement in Aotearoa at Parihaka, Taranaki was long suppressed..$^{26}$ Later, the voices of conscientious objectors to military conscription, such as Archibald Baxter and Ian Hamilton, were marginalized. ${ }^{27}$ Little has been written on peace people in the academy or for the general public with the exception of the nuclear free movement. John Urlich, former President of the NZ Peace Council, remarks, "Unless Peace groups set out to tell their own record of events there is no one left to tell the story." ${ }^{28}$ This has been the experience of many peace groups in Aotearoa NZ. Peace Activist Elsie Locke published Peace People, a broad historical survey of peace activism from pre-European Maori to $1975 .{ }^{29}$ Locke's daughter, Maire Leadbeater, continued the story of peace activism with the nuclear free movement in Peace, Power and Politics. ${ }^{30}$

\footnotetext{
22 Mention PTU relationship to NCPACS, MTM 118

${ }^{23}$ Kevin Clements, "New Wars - Olds Wars: Thinking Creatively about the Prevention and Transformation of Violent Conflict in the Twenty-First Century," in Activating Human Rights and Peace: Theories, Practices and Contexts, ed. GOH Bee Chen, Baden Offord, and Rob Garbutt (England: Ashgate Publishing, Ltd., 2012 ). 71.

24 Ibid., 71.

25 Ibid., 72.

${ }^{26}$ Dick Scott, Ask That Mountain: The Story of Parihaka (Auckland: Reed Books, 1975).

${ }^{27}$ Archibald Baxter, We Will Not Cease, 2nd ed. (Christchurch: Caxton Press, 1969); lan Hamilton, Till Human Voices Wake Us (Auckland University Press, 1953).

28 John Urlich, Journey Towards World Peace: A History of the New Zealand Peace Council (Wellington: Lake Ohia Publications, 1998). 1.

${ }^{29}$ Elsie Locke, Peace People: A History of Peace Activities in New Zealand (Christchurch: Hazard Press, 1992).

${ }^{30}$ Maire Leadbeater, Peace, Power, Politics: How New Zealand Became Nuclear Free (Dunedin: Otago University Press, 2013).
} 
All accounts emphasise that ordinary people were at the heart of activities, organisations and movements for peace.

As a self-identified 'peace person,' Gita Brooke has written much about PTU's vision and work for a culture of peace and been involved in peace activities in Aotearoa NZ since the 1980s. This thesis explores the contribution PTU has made and continues to make to a culture of peace in Aotearoa New Zealand. It examines how PTU's vision of a culture of peace has been communicated through the organisation's newsletter, MTM, through its involvement with the United Nations as an accredited NGO, and through its local activities. Using archival sources, data from interviews and a content analysis of the newsletter, and complemented by the lens of and insights from the discourse of narrative politics, this study suggests that the narrative of Peace through Unity is relevant to the discipline of International Relations (IR). It shows that the vision embodied in the unconventional model of PTU, offered opportunities to respond and evolve organically, but also put up challenges to concrete action.

This thesis troubles the tension between theory and practice, akin to that between faith in ideals and the material conditions of life, to suggest that communication or 'thought-work' carried out by the readers of MTM is action for peace. This thesis examines the agency of MTM as independent from its creator in linking and forming a network of individuals and organizations facilitating a culture of peace. It is a deterritorialised publication situated in a shared language rather than a place, enabling a sense of unity amongst readers. The thematic chapters tease the question of whether thought-work, also known as consciousness change, is the most an individual can take responsibility for in international relations. But individuals speak from specific places, raising another tension intrinsic to peace activism: how local action fits with the communication of a global vision. PTU's work shows that the two are inextricably bound together.

The who, what and how of 'Towards Peace through Unity' correspond to the three themes of MTM that structure the core chapters of this thesis. Chapter 2 on education addresses the area of 'mutual agreement' as a learning environment through MTM. Chapter 3 on transformation examines the spiritual underpinnings of PTU's vision in a 'time of unprecedented change and transformation.' Chapter 4 on responsibility looks at the power of the 'ordinary citizen of goodwill' to translate thought into action through local projects and events, using the examples of the Handspan Peace Sculpture, 2002, and celebrations of the International Day of Peace, 2015. The chapters are interconnected as each theme leads to the next one. Peace education requires consciousness transformation to that of a 
global citizen, which leads to a sense of responsibility for individual action locally. The final chapter links back to the preface to extend the brief of narrative politics and consider the importance of my research to IR. It finishes by offering directions for future research possible with such a boundless archive.

\section{Defining a culture of peace}

This thesis is located at the intersection of a number of domains: international relations, narrative politics, peace studies and print culture. This thesis gives voice to an unstudied archive which speaks to the literature of International Relations. The voices of the archive are brought into conversation with scholars in all four domains. The discourse of narrative politics enables the identification of peace visionaries, such as the Brookes, as it includes the voices of ordinary people.

Narrative politics is a relatively recent conversation in the discipline of International Relations that troubles the expertise of scholars, enables the presence of personal voice in academic writing and warns of the potential for discursive violence towards research subjects. ${ }^{31}$ Narrative politics scholar, Elizabeth Dauphinée, points out that IR is a discipline founded on the study of war and that IR scholars are thus implicated in violence. ${ }^{32}$ This connects to the concerns of Peace Studies scholars, such as Oliver Richmond, who seek to address the privileging of war over peace in IR research. ${ }^{33}$ Peace education is central to this project, as expressed in the work of H.B. Danesh, Betty Reardon and Gavriel Salomon. ${ }^{34}$ The concern with violence in the cultivation of knowledge across these fields draws the work of PTU into an academic setting, as will be demonstrated in Chapters $2-4$.

The domain of print culture enables the study of the print publication MTM and introduces a new educational environment to the above mentioned domains. It provides the conceptual tools with which to discuss the production, distribution and reception of MTM in Aotearoa NZ and as it circulates

\footnotetext{
${ }^{31}$ See Dauphinée, The Ethics of Researching War.

32 Dauphinee, "The Ethics of Autoethnography."

33 Oliver P. Richmond, "Patterns of Peace," Global Society 20, no. 4 (October 1, 2006): 367-94, doi:10.1080/13600820600929705.

34 H. B. Danesh, "Towards an Integrative Theory of Peace Education," Journal of Peace Education 3, no. 1 (March 1, 2006): 55-78, doi:10.1080/17400200500532151; Betty A. Reardon, Comprehensive Peace Education: Educating for Global Responsibility (New York, NY: Teachers College Press, Columbia University, 1988); Gavriel Salomon, Peace Education: Its Nature, Nurture and the Challenges It Faces (Springer New York, 2009), http://link.springer.com/chapter/10.1007/978-0-387-09575-2_8.
} 
in the emerging global culture of peace. MTM has agency as a vehicle of international relations, as it enables people to relate across nations, forming a web of connections in the formation of a new culture.

A central concept in this thesis is a 'culture of peace.' The concepts 'culture' and 'peace' are controversial to define and result in differing conceptualizations of a culture of peace. In general, definitions of culture can be grouped as either referring to material culture of art and artefacts or to the shared worldviews and practices of social groups. Material Culture Scholar Henry Glassie states that "culture is pattern in mind, inward, invisible, and shifting." ${ }^{35}$ It is essentially non-material, and so we can only know about culture "as it cycles in flashes and scraps through the sensate," by the way of material culture. ${ }^{36}$ Cultural theorist Stuart Hall defines culture as a process, or a set of practices, that involve the production and exchange of meanings. ${ }^{37}$

Peace is a contested concept in International Relations that is at once integral to the discipline and dismissed as being unattainable. Richmond identifies nine patterns of thought on peace in IR, seven of which are aggregated as the most common conception of peace: "the liberal peace." ${ }^{38}$ Overall, the liberal peace considers governance as integral to peace in nation-states. The liberal peace is critiqued by the "local turn" in peacebuilding, which questions the top-down construction of peace by external actors in post-conflict zones, suggesting instead that sustainable peace is best created by local actors. ${ }^{39}$ Scholar-practitioner John Paul Lederach explains models for peacebuilding at the local level with a focus on reconciliation of divided societies. ${ }^{40} \mathrm{He}$ highlights the importance of mid-range leaders in connecting the elite and the grassroots levels of society, emphasising the importance of networks and relationships to reconciliation. These conceptions of peace will be referred to in Chapter 4 on responsibility.

What is a culture of peace? Firstly, there is a difference in singular and plural uses of the concept. Clements, cited above, refers to "cultures of peace," implying multiple communities in which

\footnotetext{
${ }^{35}$ Henry Glassie, "Material Culture," in Material Culture (Bloomington \& Indianapolis: Indiana University Press, 1991), 41.

36 Ibid.

${ }^{37}$ Cynthia Weber, International Relations Theory: A Critical Introduction, 3rd ed. (New York, N.Y., United States: Routledge, 2010), 3.

38 Oliver Richmond, 'Patterns of Peace,' Global Society 20, no.4 (2006), 380.

${ }^{39}$ Roger Mac Ginty and Oliver P Richmond, "The Local Turn in Peace Building: A Critical Agenda for Peace," Third World Quarterly 34, no. 5 (June 1, 2013): 763, doi:10.1080/01436597.2013.800750.

40 John Lederach, Building Peace: Sustainable Reconciliation in Divided Societies (Washington, DC: United States Institute of Peace Press, 1997).
} 
peace cultures are present. ${ }^{41}$ Clements implies that various conceptions of peace may differ depending on the context. This view is reflected in anthropological studies that seek to identify peaceful cultures existing within dominant cultures. However, most authors speak of one culture of peace as an alternative to the hegemonic culture of war that pervades most societies. ${ }^{42}$ This dichotomy suggests that just as humans have the capacity for violence, they also have a capacity for peace, and the hegemonic culture decides which capacity is most developed through the process of education. Whether in the singular or plural, a culture of peace here refers to social practices and ways of life.

A singular culture of peace is also used for the implication of universal oneness or unity. David Adams, former UNESCO Director for the unit of the International Year for a Culture of Peace, emphasizes that a culture of war is dominant globally, and so a culture of peace must be universal to truly transform the existing world order. ${ }^{43}$ This fits with the universal vision of the United Nations. Federico Mayor Zaragoza, former Director-General of UNESCO (1987-1999), set up the Foundation for a Culture of Peace in Spain to enable the transition to a culture of peace. ${ }^{44}$ Indeed, UNESCO is another key archive for writings on a culture of peace. Mayor and Adams were influential in the writing of the draft Declaration and Programme of Action on a Culture of Peace, adopted by the UN General Assembly in September 1999. ${ }^{45}$ Again, emphasizing that culture is the expression of internal patterns of thought, the Declaration states that, "A culture of peace is a set of values, attitudes, traditions and modes of behaviour and ways of life." 46

PTU adopts the concept of a culture of peace as one global way of life based on the values of cooperation, respect and unity. As Gita Brooke states in MTM, "We - all of us - must become involved and work together for such a culture to come about. A sense of unity - within which all cultural, religious

\footnotetext{
${ }^{41}$ Clements, "New Wars - Olds Wars: Thinking Creatively about the Prevention and Transformation of Violent Conflict in the Twenty-First Century."

${ }^{42}$ Elise Boulding, Cultures of Peace: The Hidden Side of History (Syracuse University Press, 2000); Joseph de Rivera, "Introduction," in Handbook on Building Cultures of Peace, ed. Joseph de Rivera, Peace Psychology Book Series (Springer New York, 2009), 1-8, http://link.springer.com/chapter/10.1007/978-0-387-09575-2_1; Reardon, Comprehensive Peace Education: Educating for Global Responsibility; Danesh, "Towards an Integrative Theory of Peace Education"; Salomon, Peace Education.

${ }^{43}$ David Adams, "Culture or Cultures of Peace?," Culture of Peace, accessed January 11, 2016, http://culture-ofpeace.info/vita/2010/Culture_or_Cultures_of_Peace.html. 44 "IPS - Inter Press Service News Agency » Federico Mayor Zaragoza," accessed March 21, 2016, http://www.ips.org/institutional/our-global-structure/biographies/federico-mayor-zaragoza/; Federico Mayor Zaragoza, "The Crime of Silence," Www.fund-Culturadepaz.org, accessed March 22, 2016, The_Crime_of_Silence_FM.pdf.

${ }^{45}$ United Nations Declaration and Programme of Action on a Culture of Peace, A/RES/53/243, 1999, undocuments.net/a53r243a.htm.

${ }^{46}$ Ibid.
} 
and racial differences are recognized and respected - must be established as the firm foundation on which a culture of peace can be built." ${ }^{47}$ The abstract values of a culture of peace are expressed in material culture, which is also destroyed in war. PTU has adopted and promoted the banner of peace, in reference to Russian Artist Nicholas Roerich, as a symbol to protect cultural sites of importance. ${ }^{48}$ As such PTU uses culture in both senses of the concept: abstract and material.

PTU adopts and diverges from the concept of peace offered by UNESCO. The Declaration and Programme of Action on a Culture of Peace draws on the 'liberal peace' as the concept of peace underlying its definition. Much of PTU's work has been in response to the Declaration. But this does not mean they have replicated liberal peacebuilding projects which have been critiqued by the local turn. Peacebuilding, as in developing the capacities of communities to transition to a culture of peace, takes different forms in Aotearoa NZ as it is not a place of hot conflict. That the Handspan Sculpture was a direct response to the Declaration highlights the agency of civil society to translate UN calls to action locally, despite the conceptual origins and presence of active conflict. Salomon states that the Declaration was intended for situations of active conflict. ${ }^{49}$ Yet, violence is still pervasive in interpersonal relations. PTU diverges from the peace-as-governance in that they view the origins of violence as internal, within humans, and so peace must emerge from within rather than be implemented from without. As Gita Brooke declares, "Peace cannot invade a country, a culture, or a person. ... It is a process of change and transformation from the inside out - for all of us." ${ }^{50}$

For the purposes of this thesis, a culture of peace is defined as a global network of readers who share information and activities for peace. It treats a culture of peace as in formation to emphasise the process and activity involved in cultural change. It is an unfinished project with sites of uneven development, as reflected in the body of academic literature as well as in situated sites of knowledge and learning.

${ }^{47}$ Gita Brooke, “Creating a Culture of Peace: Banner of Peace - Manifesto 2000,” Many to Many, no. 83 (March 2003): 4.

48 Ibid.

${ }^{49}$ Salomon, Peace Education.

${ }^{50}$ Gita Brooke, "Philosophical Reflections: The UN and a New World Order" (The United Nations Association of New Zealand Seminar on Global Governance and UN Reform, Wellington, New Zealand, June 25, 1993). 


\section{Context and background to Peace through Unity and newsletter 'Many to Many'}

As an organization, PTU is unconventional as it has no formal membership structure and had no permanent address for much of its existence, relying on temporary bases in places such as London, UK, Banff, Canada, Santa Fe, USA, and Paekakariki, NZ. ${ }^{51}$ This posed challenges, but it also gave great opportunity for flexibility and evolution. I use PTU to refer to the Brookes and their network of coworkers around the world. Key co-workers include Iris Spellings, who has represented PTU at the United Nations in New York City since 1999, and Steve Nation, who manages PTU's website and edits and distributes MTM. A key co-worker in Whanganui is Kate Smith, President of the Whanganui Branch of the United Nations Association NZ (UNANZ). I have been in contact with all three key co-workers for this thesis. Past co-workers also included Dame Laurie Salas, previous National President of UNANZ and many others as evident in MTM.

The vision of PTU was influenced both by Gita and Anthony's experiences in life. Gita and Anthony Brooke worked in partnership, "back to back and gaze directed outwards," for their many years of travel and settlement in Whanganui. ${ }^{52}$ Anthony Brooke was last in line to the Rajah Muda of Sarawak before the small territory, now part of Malaysia, was ceded in Britain after WWII. Anthony fought the undemocratic decision and was exiled from Sarawak soon after. Prepared to serve the people of Sarawak, Brooke redirected his energies to serving humanity as a whole when that path was closed to him..$^{53}$ Brooke's strengths included the public roles of speech-making, campaigning and networking which he brought to PTU. That part of Anthony Brooke's story was already in the past by the time he met Gita in the 1970s, although in 1983 she accompanied him on his first visit to Sarawak since his exile, and he retained a lifelong concern for Sarawak. ${ }^{54}$ The Brooke history is in the process of being archived and told by the Brooke Heritage Trust, in conjunction with Oxford University, PTU and Sarawak..$^{55}$

This thesis is particularly concerned with Gita Brooke's story as part of PTU which is at risk of being unrecorded in Brooke focused narratives. Gita is the living co-founder of PTU and wrote most of

\footnotetext{
${ }^{51}$ Based on the addresses given in Phase 1-2 of MTM

52 Gita Brooke, Interview 2, August 25, 2015.

53 Anthony Brooke, "Anthony's Story - After Sarawak, 1951-1970," Operation Peace Through Unity, accessed January 12, 2016, http://www.peacethroughunity.info/background-anthonystory7.html.

${ }^{54}$ Anthony Brooke, “Anthony's Story - Continued, Visiting Sarawak 1983 \& 1991," Operation Peace Through Unity, accessed January 12, 2016, http://www.peacethroughunity.info/background-anthonystory9.html\#here. 55 "Brooke Heritage Trust," Brooke Heritage Trust, accessed February 11, 2016, http://www.brooketrust.org/.
} 
PTU's extensive archive of letters, reports, and pamphlets and MTM, according to her strengths. Born in 1931 in Copenhagen, Gita spent the first five years of her life in Tamil Nadu, southern India where her parents, Paul Hjorth Lange and Signe Lange, were missionaries. ${ }^{56}$ The family returned to Copenhagen circa 1936 in order to recover their health. ${ }^{57}$ They moved in the island of Bornholm where they stayed during World War II. ${ }^{58}$ Paul Lange was part of the Danish resistance to the German occupation of Denmark and the family went into hiding during Gita's early teenage years. ${ }^{59}$ Her worldview and conviction for peace were profoundly shaped by her experience during and after the war. When "peace broke out," a young Gita saw the war go "underground, within people."60 The human capacity for violence, separatism and hate manifested during active conflict were not worked through or healed, revealing to Gita that it was not so clear cut as good and bad, all carried the potential for peaceful or violent behaviour. ${ }^{61}$ Gita spent her most of her adulthood in Scandinavia and had been living near Gothenburg, Sweden for fifteen years before travelling with Anthony Brooke as PTU. ${ }^{62}$

In the early 1990s, PTU was accredited non-governmental organization (NGO) status by the United Nations Department of Public Information (UNDPI), the part of the UN that deals with civil society and NGOs. They had been motivated by the vision of the UN charter for 'we, the peoples' since the beginning and had worked on the UN disarmament campaign and others during their travels. They had also regularly sent reports of their work and travels and MTM to the UN DPI. PTU helped prepare the ground for UN RES/53/243, Declaration and Program of Action on a Culture of Peace. The wide scope of the document affirms the work that PTU had been doing all along for the nascent global movement for a culture of peace. However, the lack of a steady address was a barrier to official recognition. With the help of a contact at the UNDPI who believed PTU filled the UN brief as to the purpose of civil society organizations better than most, and a steady NZ address, PTU gained UN accreditation.

Information from the UNDPI was slow to reach the Brookes, even when they had settled in NZ, due to geographic distance from the UN headquarters in New York City. PTU frequently missed response deadlines for reports on activities and NGO surveys because the mail reached Aotearoa NZ

\footnotetext{
${ }^{56}$ Brooke, Interview 1.

${ }^{57}$ Ibid.

58 Ibid.

59 Ibid.

${ }^{60}$ Ibid.

${ }^{61}$ Ibid.

${ }^{62}$ Ibid.
} 
past the deadline. Co-worker Iris Spellings, who lives in NYC, filled an essential role for PTU in that she could respond more quickly to requests for information. Communications challenges were mostly solved in the new millennium by fax and email.

However, the unconventional model of PTU remains a barrier to full participation in the UN NGO system. PTU is a structureless organization based on a self-identifying affiliation of co-workers. The horizontal nature of this network was chosen by the cofounders to allow PTU to evolve organically and to make decisions faster. This was a progressive move at odds with the hierarchal state system, and the hierarchal member-state system of the UN. NGOs that are part of the UN system are required to fit a hierarchal model of governance which does not reflect the ideals of PTU. As Spellings frequently explains to NGO colleagues at the UN, "PTU has no board of directors." ${ }^{63}$ Nor is it backed by a large funding body. Spellings is a volunteer. Practically speaking, PTU can respond faster without having to seek approval from a board or committee. The progressive, horizontal network of PTU shows huge faith in fellow people to do the work that needs to be done. This is a principle that cannot be sacrificed by Brooke as it underlies the core of PTU's spiritual vision, as will be discussed in Chapter 3, and is how it operates practically. The challenges and opportunities afforded by PTU's unconventional structure will be shown through detailed examples in Chapter 4.

Even though PTU submit yearly reports to the UN DPI and Spellings continues to actively represent in person, PTU does not show up on the database of NGOs available online. ${ }^{64}$ PTU has also not been able to gain status with the Economic and Social Council (ECOSOC) because they do not meet the criteria. ${ }^{65}$ Despite this, Spellings is active in many UN NGO working groups and committees. PTU was a founding member of the Global Movement for a Culture of Peace (GMCOP) in 2001, a consortium of NGOs working to implement UN RES 53/243. ${ }^{66}$ They are also a founding member of the Committee on Spirituality, Values and Global Concerns (CSVGC) in 2004, a committee of the Conference of NGOs in Consultative Relationship with the UN (CONGO). ${ }^{67}$ Spellings has done much organizational work for the High Level Forum for a Culture of Peace annually as part of the International Day of Peace events. ${ }^{68}$

\footnotetext{
${ }^{63}$ Iris Spellings, Personal Communications, November 17, 2015.

64 "United Nations Civil Society Participation - Department of Public Information," accessed March 21, 2016, http://esango.un.org/civilsociety/displayDPISearch.do?method=redefine.

${ }^{65}$ Spellings, Personal Communications.

${ }^{66} \mathrm{Ibid}$.

${ }^{67}$ Ibid.

68 Ibid.
} 
Spellings and PTU co-workers Nation and Sharon Deep are also on the Council of the Spiritual Caucus at the UN. ${ }^{69}$ PTU has found ways to work within the current system.

As well as global actions, PTU also works locally to organize events in Whanganui, Aotearoa NZ, in support of global campaigns and UN commemorative years. Perhaps most memorable for the Whanganui community is the Handspan Peace Sculpture in Queen's Park, built in 2002 to promote the UN International Decade for Peace and Non-violence for the Children of the World. ${ }^{70}$ The unique work of art features thousands of clay hands cast from people in the community, united in a double spiral path, rising to a central meeting point overlooking the city. Gita Brooke worked tirelessly to ensure the involvement of as many community members as possible, as she had in the 1995 commemorative weekend of events for the $50^{\text {th }}$ anniversary of the UN. Since 2002, PTU and the Whanganui UNANZ branch annually organize celebrations for the United Nations International Day of Peace, September 21. The dedication of the Handspan Sculpture by Dame Silvia Cartwright, Governor General, took place on the Day of Peace and forms a focal point for commemorations in Whanganui. ${ }^{71}$

\section{Identifying and foreshadowing central themes}

The first issue of Many to Many (MTM) was published by PTU in 1982 in cooperation with another NGO based in Canada, who suggested the name. ${ }^{72}$ This NGO did not continue with the publication but were happy for Gita Brooke to keep the name and continue MTM herself. Brooke continues to collate and write the extended newsletter to this day, although since 2012, publication has been reduced from quarterly issues to three times a year. The format of the publication has been streamlined over the years but has remained reasonably consistent as a substantial 15 page document.

Soon after it began, Brooke counted over 50 countries, spread across 4 continents, on the mailing list. ${ }^{73}$ In 2006, distribution changed to email subscriptions (free of charge) managed by PTU Coworker Steve Nation. There are currently 101 subscribers on the email list. ${ }^{74}$ Brooke continues to mail

\footnotetext{
69 "The Spiritual Caucus at the United Nations," accessed March 21, 2016, http://www.spiritualcaucusun.org/.

${ }^{70}$ Gita Brooke, ed., Wanganui Culture of Peace 2002 (Wanganui: Peace Through Unity, 2002).

${ }^{71}$ Gita Brooke, "21 September - The International Day of Peace (Wanganui Culture of Peace Work of Art)," Many to Many, no. 81 (September 2002).

${ }^{72}$ Gita Brooke, Interview 3, November 13, 2015.

${ }^{73} \mathrm{Ibid}$.

${ }^{74}$ Steve Nation, Personal Communications, November 24, 2015.
} 
some copies by post and gives printed versions to friends, making the total number of readers unclear. All copies are part of the archive at Te Rangi, the Brookes' house in Whanganui, except for a small number of missing issues including the first. All issues from 1991 to the present are also available at the National Library of NZ. ${ }^{75}$

MTM can be grouped into four phases that reflect the focus and position of PTU at the time. These phases flow into one another and were not conscious decisions on the part of Brooke. ${ }^{76}$ The first phase (1982-1989) is comprised of letters received from individuals and some organizations, sent to the PTU Sante Fe base, during the Brookes' time of extensive travel. The letters from individuals were creative and imaginative visions and thoughts on what peace is and how to achieve it. At first Gita solicited and relied solely on these unedited letters for the contents of MTM, which she simply photocopied and attached to a contents page and opening letter from the Brookes.

However, it was difficult soliciting and receiving letters in a timely way when the Brookes were constantly on the move, even with friends in Banff, Canada, collating and photocopying letters for them. ${ }^{77}$ The second phase (1990-1997) still features letters from individuals but there are more from organizations in regard to specific campaigns. There are regular updates on the Antarctic Peace Park campaign and the state of the rainforests in Sarawak under threat from logging. More editorial work is done by Gita Brooke in selecting and writing articles.

Phase two and three merge into one another but they can be distinguished by marking the time PTU gained UN accreditation. During the late 1990s, there is a rise in UN sourced content, reflecting PTU's status as an accredited NGO and increased access to information from the UNDPI. Brooke consciously included more UN content as she felt it was their duty as an accredited NGO to network information on UN activities and agencies. The fourth phase, (2006-present), has been consistent in content and focus. Now, the publication is almost entirely UN sourced content, representing a broad range of issues, with at least one local item and contributions from co-workers per issue. Each issue starts with a contents page and an editorial written by Brooke and finishes with the prayer, The Great Invocation.

Phase three is also distinguishable from Phase two as the content of MTM was accessible online. Issues 62, December 1997 - 80, June 2002 are available in the Glastonbury Archive, hosted free by the Isle of Avalon web platform and maintained by co-workers Larry Matthews in Christchurch, NZ,

\footnotetext{
${ }^{75}$ Brooke was informed of Legal Deposit as a legislative requirement in 1991.

${ }^{76}$ See Appendices 1-4 for examples of the contents pages from each phase.

77 Gita Brooke, ed., Many to Many, no. 2 (December 1982): 1-13.
} 
and Palden Jenkins, Glastonbury, UK. ${ }^{78}$ Issues 71, March 2000 - 94, December 2005, are available to read in a simpler format on the Angel Fire web platform. ${ }^{79}$ Phase Four is also marked by the fact that PTU got their own website and domain name, created and maintained by Steve Nation, in which issues 95, Mar 2006, to the present are available to download as word files. ${ }^{80}$ Nation emails subscribers a link to the most recent issue when it is posted on the website.

After a couple of pilot tests, I abstracted three themes (education, transformation and responsibility) from the pamphlet, 'Towards Peace through Unity,' then used them as integrative lenses to analyse the content of MTM and interviews. Selecting the themes allowed me to isolate and categorise the keywords present in MTM (see Table 1 below) which were then trialled on Issue 96, June 2006. All three themes were present, but the content was weighted to the theme of transformation. I ran the .txt file through Voyant, a web based tool for the analysis of digital texts, to check my manual coding of the categories. Voyant shows the most common words in a file (excluding articles etc.) allowing me to check my identification of keywords and plot them in tables under the three themes to check my coding. I then trialled all four phases of MTM in this way. The themes are consistent across the phases of MTM, but with varying emphases depending on the location of PTU, alignment to the UN and Brooke's capacity to publish.

Table 1: Themes and corresponding keywords of Many to Many

\begin{tabular}{|c|c|c|}
\hline Education & Transformation & Responsibility \\
\hline $\begin{array}{l}\text { Mindset, thought } \\
\text { Youth, children } \\
\text { Peace, conflict resolution, non- } \\
\text { violence } \\
\text { understanding, communication, } \\
\text { information }\end{array}$ & $\begin{array}{l}\text { Planet, earth } \\
\text { Environment, nature } \\
\text { Relationships, community } \\
\text { Mindset, thought } \\
\text { World order, civilisation } \\
\text { Spirit, heal, heart, faith, goodwill, } \\
\text { tolerance, unity }\end{array}$ & $\begin{array}{l}\text { United Nations } \\
\text { 'We, the peoples' } \\
\text { Cooperation } \\
\text { Leadership } \\
\text { Respect, human } \\
\text { rights } \\
\text { global, citizen }\end{array}$ \\
\hline
\end{tabular}

78 "Operation Peace through Unity," Glastonbury Archive, Isle of Avalon, accessed March 22, 2016, http://www.isleofavalon.co.uk/GlastonburyArchive/manymany/issue-62/mm-62h.html. 79 "The Homepage of Gita and Anthony Brooke," Angel Fire, accessed March 22, 2016, http://www.angelfire.com/journal/brooke2000/. 80 "Many to Many Current," Operation Peace Through Unity, accessed March 21, 2016, http://www.peacethroughunity.info/manytomany_current.html. 
Content analysis was useful for identifying the consistency of PTU's vision through the abstraction of keywords and themes. However, it risked losing some of the figurative language favoured by Brooke and contributors. To make the most of the richness of the text, I also practised the techniques of close reading, thus mixing qualitative and quantitative digital humanities methods.

The three themes directly stem from the vision of PTU outlined in the 1975 pamphlet. The theme of education relates to the 'how,' an 'area of mutual agreement,' which I suggest is a learning environment conducive to thought-work. The theme of transformation relates to the 'when,' a 'time of unprecedented change and transformation,' as the context of the spiritual framework of the vision laid out in the seven points of the pamphlet. The theme of responsibility looks at the opportunities and challenges to action faced by the 'who,' the 'ordinary citizen[s] of goodwill,' as readers of MTM and coworkers of PTU. Each chapter discusses the how, when and who in relation to the corresponding theme in more detail to show the dynamics of communication or 'thought-work' as action for peace. Evidence is drawn from the various phases of MTM to support the analysis of each theme. 


\section{Chapter 2: Education}

"In the task of seeking out areas of mutual understanding and co-operation, a movement towards a resolution of conflict situations can often be furthered from a basis of mutual agreement where this is found possible at a level transcending areas of specific disagreement, and common meeting points become more readily possible when an agreed mutual stance can first be taken at this deeper level of communication." $" 81$

\section{Many educating many: an area of mutual agreement in print}

The focus of this chapter is to examine the role Many to Many (MTM) plays in regard to education for a culture of peace. I maintain that education is integral to the formation of a culture of peace due to the potential for worldview transformation. I propose that an area of mutual agreement is a learning environment conducive to the formation of worldviews based on unity rather than separatism. PTU fashioned an area of mutual agreement on the printed pages of $M T M$, raising the question of how the publication contributed to consciousness change akin to the project of peace education. The publication has agency independent from its collator and writer, Gita Brooke, in that it travelled through many hands connecting people in all kinds of (un)intended ways. The agency of MTM lead the way to a sense of unity amongst contributors and readers who shared information and were inspired by each other's activities for peace to act themselves.

MTM provides a unique source of evidence as to the educational activities of actors working to form a culture of peace, as well as being a means of education in itself. The publication provides a space for like-minded people to come together, in a sense, and share their thoughts, visions and activities for peace. Even though the contributors came from over 50 countries with different cultural backgrounds and perspectives, they shared an individual and collective commitment to peace. This interpretation fits the purpose of $M T M$ as a "communicating link ... for the furthering of better

\footnotetext{
${ }^{81}$ Brooke, "Towards Peace Through Unity."
} 
relationships based on ... mutual understanding ... unity and cooperation beyond all differences." 82 Education is treated as a way to mutual understanding through the area of mutual agreement.

This area of mutual agreement overlapped with international networks of educators based in universities, museums, governments, religious sites, intentional communities, the UN DPI and UNESCO who regularly contributed to the publication via written correspondence with Brooke. These sites of education are both formal and informal, giving a glimpse of the complex processes and places of learning about peace. PTU's vision for individual and collective change is shared by peace educators and 'ordinary citizens' who were connected through MTM.

A theorist drawn on by this chapter, Betty Reardon, was part of the network of readers and contributors to MTM. There is a letter from Reardon in the December 1988 issue sharing her latest activities for peace education in her role at the Teacher's College Columbia University, New York. ${ }^{83}$ Her opening line, "As always, it is wonderful to receive the number of 'Operation Peace Through Unity,'” suggests she is a regular reader and subscriber ${ }^{84}$ Reardon has been establishing an "international consortium of International Institutes for Peace Education" and invites readers to contact her for more information. ${ }^{85}$ The Peace Education Program has received a grant from the United States Institutes for Peace to develop curricula on Human Rights. ${ }^{86}$ The letter gives "many new reasons to be hopeful" not least of which is "the great surge of interest and activity" evident in recent conferences Reardon attended in Bonn and Rio. ${ }^{87}$ She thanks Brooke for her work "linking and networking these hopeful signs." 88 That a foremost teacher and academic took the time to write to Brooke and address the readers of MTM shows the importance ascribed to this network of information sharing. The information PTU networked was great inspiration for readers and fellow peace-workers.

The Brookes' experiences while travelling reinforced the viability of the vision of PTU and that was possible to form an area of mutual agreement towards joint understanding and cooperation. During their travels, Gita and Anthony Brooke met with government officials, priests and ministers, disarmament activists, students and many, many individuals. They approached each conversation with a view to starting from an area of mutual agreement. One of Gita Brooke's best remembered meetings

\footnotetext{
82 See the first page of any issue of 'Many to Many' for the full vision statement

${ }^{83}$ Betty A. Reardon, Many to Many, no. 26 (December 1988): 5.

${ }^{84} \mathrm{Ibid}$.

${ }^{85} \mathrm{Ibid}$.

${ }^{86}$ Ibid.

${ }^{87}$ Ibid.

${ }^{88}$ Ibid.
} 
was with a Russian government official during a "very cold, cold period of the Cold War." The Brookes' listened attentively as the man told them what he believed to be the problem and gave them the "political agenda." ${ }^{\prime 99}$ Gita Brooke emphasizes that they really listened without interrupting. When the official had finished, a "pause developed," and so he asked the Brookes a question. ${ }^{90}$ They presented an area of mutual agreement and how it was needed in Russia, the UK, the USA: everywhere. With that, "the professional façade fell off" and "he became a father who was worried" for his children. ${ }^{91}$ Gita Brooke remembers that "he had done what he was expected to do and then came out the father, and we could talk." ${ }^{\prime 2}$ In this case, the willingness of the Brookes to listen led the way to the area of mutual agreement, in practice and in conversation. It could not be created until the professional role gave way to the personal, through which a human to human connection could be formed.

The area of mutual agreement is a learning environment in which people can openly share their perspectives and come to understand one another. The citizens of goodwill "share a concern to live and work in a way that serves to widen, deepen and intensify areas of mutual understanding." 93 An area of mutual agreement is a strategy to bridge differences when forming relationships as a way to changing worldviews. An area of mutual agreement does not require complete worldview transformation to begin with. Rather, it tries to address the difficulties we have in recognizing our shared humanity and concerns and in transforming our patterns of thought, our culture, which may lead to worldview transformation. Introducing an area of mutual agreement as a learning environment can help in the process of changing conflict based worldviews to those more conducive to a culture of peace.

As a learning environment an area of mutual agreement need not be situated in a physical space, such as a classroom or diplomat's office although these can be sites of learning. An area of mutual agreement is formed through deterritorialized conversations on the pages of MTM as readers engage with PTU and each other. There is not much evidence of disagreements across the pages of MTM. In Phase one the letters sent by contributors shared similar visions for peace and the oneness of humanity. Nor did I find evidence of much disagreement with Brooke's editorial standpoint. MTM contributes to conversation and provides inspiration, as suggested by Steve Nation, and promotes unity

\footnotetext{
${ }^{89}$ Brooke, Interview 2.

90 Ibid.

91 Ibid.

92 Ibid.

93 Brooke, "Towards Peace Through Unity."
} 
through the building of a knowledge base. ${ }^{94}$ The model of a many to many relationship in systems theory refers to the spread of information through multiple sources, an accurate way of envisaging the distribution of 'Many to Many.'

UNESCO also recognizes the value of information sharing on a culture of peace as a way to build mutual understanding on a framework of peace. An example of an initiative in this regard is the Culture of Peace (COP) News Network, a web platform on which individuals and/or organizations can share their activities. An invitation to contribute was extended to the readers of MTM in the June 2013 issue. $^{95}$ The COP news network complemented the MTM network. For example David Kimball, contributor to the December 2004 issue, found MTM via the COP news network. ${ }^{96}$ MTM itself was by this stage available online and distributed via email. The sharing of activities for peace was a gauge for how the formation of a culture of peace was progressing. These activities are often left out of mainstream reporting making it difficult to educate and change worldviews as to the feasibility and progress of a culture of peace. MTM was part of a network of individuals and news publications that helped publicize initiatives in this regard.

MTM offers an alternative narrative with which to view the international sphere, one in which everyday people are the main actors in creating peace. In this way it is involved in a consciousness changing project. It is like the process of gaining critical awareness described by educator Paulo Freire - as one becomes aware of their part in systems of violence, they change their mind-set so as to act differently. ${ }^{97}$ Thinking about education in this context links to awareness activism and the commonly held view that increasing one's knowledge of the topic, countering ignorance, is most of the work for social change. It is an indirect form of activism that aims to change behaviour as readers internalize the possibility of living peacefully.

\footnotetext{
${ }^{94}$ Nation, Personal Communications.

${ }^{95}$ Gita Brooke, ed., “Become a Culture of Peace Reporter," Many to Many, no. 124 (June 2013).

${ }^{96}$ Helen Huber and David Kimball, "Building a Culture of Peace and the Evolution of Consciousness Responses," Many to Many, no. 90 (December 2004): 13-14.

97 Paulo Freire, Pedagogy of the Oppressed (England: Penguin, 1996), 33.
} 


\section{Peace education as the promotion of unity}

The core concept behind the creation of an area of mutual agreement is that of unity. Starting from what we have in common, rather than our differences, leads to more progress in conversation towards mutual understanding and cooperation. Gita Brooke sees quite clearly that starting from the point of "complicatedness," our many differences, leads to 'for or against' arguments. ${ }^{98}$ This is especially the case for individuals implicated in a conflict situation, who may have strong opinions and beliefs about what the problem is and what should be done. Difference as a starting point to conversation often "leads nowhere," other than to "further fermenting disagreements." ${ }^{99}$ PTU's suggestion was that conversation begins from the simplest points of what the individual's share, from a point of unity, as to avoid immediate confrontation provoking a defensive and offensive reaction. ${ }^{100}$ The simple, shared starting points could be that we are both human, or that we are parents concerned for our children, as was the case in the meeting with the Russian official. Once a basis of unity is established, then the various issues can be laid out, addressed from different stances and solved, within "the sphere of mutual agreement." 101 Gita described this as starting from "strength," that unity is firm ground to start from. ${ }^{102}$

Peace educators and theorists Betty Reardon and H.B. Danesh recognize that the concept of unity is crucial to educating towards peace. It is important because these scholars hold that unity is the basis of peace, and the way to peace. Danesh proposes that we need to teach and adopt a unity-based worldview as the first prerequisite for effective peace education. ${ }^{103}$ Danesh defines worldview as our view of reality, human nature, purpose of life and human relationships. ${ }^{104}$ Education is important to peace because our worldviews are shaped and formed by our education - in and outside school. Danesh argues that most cultures teach and hold conflict based worldviews, which he breaks down as survivalbased worldview and identity-based worldview. ${ }^{105} \mathrm{~A}$ unity-based worldview teaches the values of harmony, cooperation and interconnectedness as the basis of life for humans, rather than life as

\footnotetext{
${ }^{98}$ Brooke, Interview 2.

${ }^{99} \mathrm{lbid}$.

100 Ibid.

101 Ibid.

102 Ibid.

${ }^{103}$ Danesh, "Towards an Integrative Theory of Peace Education," 66-67.

${ }^{104}$ Ibid., 66.

${ }^{105}$ Ibid., 66-67.
} 
competition for survival at the root of conflict-based worldviews. ${ }^{106}$ At the core of the unity-based worldview is the belief that humanity is one. To unite means to make one, to bring together as a whole, and so unity is a state of oneness. World citizenship creates the sense of the oneness of humanity (a point to be discussed more in the chapter on responsibility).

However, the problem is one of accommodating difference. As noted by Danesh, unity is an "all-important but little-understood concept," that I would add has been much maligned because in practice it has been used by those with power to mask difference, to enforce conformity and to punish deviance. ${ }^{107}$ Social movements and NGOs are not immune from these pitfalls and yet forging a transnational or global movement with a shared identity and purpose necessitates connection across borders. Greta Snyder asserts that direct engagement with difference is necessary to forge global movements in Recognition and Global Politics. ${ }^{108}$ Snyder suggests an "integrative recognition politics brings the worldviews of different groups into closer alignment and enables diverse groups to act together." 109 This takes Danesh's conception of a unity-based worldview into the broader context of cooperative social movements, while not suggesting diverse movements must collapse into sameness to work together. Danesh addresses difference through the phrase "unity in diversity." 110 Unity does not mean we must all conform to sameness, but that despite our differences we can work together for the common good. Snyder also uses this phrase as it draws attention to the "multiplicity of an identity category." 111 PTU describes how the citizen of goodwill negotiates unity in diversity: "While giving due recognition to differences which should be both acknowledged and respected, they are not concerned to give their energies to being argumentative over these differences, but are concerned rather to keep their vision and their energies steadily focused upon unitive possibilities in all their relationships." 112 Creating an area of mutual agreement is the most important task of peacemakers.

MTM described the unity-based worldviews of readers and their efforts to live out these worldviews. In this way, it helped peace workers gain recognition for their efforts. Joseph Abileah, a now well-known Israeli pacifist, wrote a letter titled, 'The Bridge of Peace' published in the second issue

\footnotetext{
106 Ibid., 68.

107 Ibid.

${ }^{108}$ Greta Fowler Snyder, "Recognition in the Struggle against Global Injustice," in Recognition and Global Politics: Critical Encounters Between State and World, ed. Patrick Hayden and Kate Schick (Manchester: Manchester University Press, 2016), 176.

109 Ibid.

110 Danesh, "Towards an Integrative Theory of Peace Education," 66.

${ }^{111}$ Snyder, "Recognition in the Struggle against Global Injustice," 178.

112 Brooke, "Towards Peace Through Unity."
} 
of MTM, and wrote again in issue eleven. ${ }^{113}$ The latter describes Abileah's vision for a bridge to peace, "built on four pillars: 1. The sisterhood and brotherhood of humankind. 2. The holiness of life. 3. Nonviolence and truth, and 4. Good ways to good ends. These pillars must be fixed on either sides of the abyss on two mighty rocks which are faith and hope." 114 Abileah highlights his belief in one humanity as related and a family, 'sisterhood and brotherhood,' a central value of unity-based worldviews evident throughout contributions to MTM. These four pillars foreshadow the seven points of PTU's vision, to be discussed later in this thesis, as both are spiritual visions as suggested by pillar two, 'the holiness of life.'

The political implications of these values are identified, as Abileah says, "Truth has never been tried in politics. I would suggest to start trying, may be it works?"115 Although peace activism for political ends can seem like an oxymoron, peaceful and non-violent resistance has been effective in many cases. Pillar four also highlights the importance of process to PTU and other activists and organisations. Abileah captures the belief that moral action for the achievement of goals when he says, "We might reach other results than those envisioned but certainly good ones and, moreover, are left with the feeling that we have not harmed or destroyed anybody or anything on our way." 116 In this view, moral processes can only lead to good results, even if unintended. Abileah's letter offers a good example of the visions shared in MTM that complemented PTU's vision and highlights the reach of the network in creating an area of mutual agreement.

Abileah also shows how peace activists were part of wider communities, some of these intentional, as Abileah was connected to Wahat Al-Salaam/Neve Shalom. Priest Kenyon Wright wellremembers Abileah taking him to Wahat Al-Salaam/Neve Shalom during his visit in $1976 .{ }^{117}$ This intentional community, meaning 'Oasis of Peace,' is an existing settlement and school of peace for Arabs and Jews in Israel/Palestine. The school of peace in an integral part of the project to enable dialogue between Arabs and Jews as a way to living together peacefully. The intentional community was also a regular contributor to MTM. Issue 25 features an introductory page to the community and

\footnotetext{
113 Israeli Pacifist: The Life of Joseph Abileah (Diane Pub Co, 1990); Joseph Abileah, "The Bridge to Peace," Many to Many, no. 2 (December 1982): 6; Joseph Abileah, ed. Gita Brooke, Many to Many, no. 11 (March 1985): 8.

114 Abileah, "The Bridge to Peace."

115 Ibid.

116 Ibid.

${ }^{117}$ Kenyon Wright, Coventry - Cathedral of Peace: Healing the Wounds of History in International Reconciliation (AuthorHouse, 2012).
} 
School of Peace and regular updates follow. ${ }^{118}$ In 1998, the community reaches out to the network of MTM for support as its existence is under threat by new land legislation. ${ }^{119}$ MTM served international and overlapping networks of peace people by enabling communication and connection.

Yet the majority of MTM readers and contributors were unknown to each other or to the Brookes. I make this point as it is addressed in 'Towards PTU.' The 'ordinary citizens of goodwill' as described as "a relatively small minority" who most often work "anonymously behind the scenes." 120 This is true of the way in which PTU works. Gita Brooke acts as the initiator or catalyst for projects in which other people take on a more public role, such as in the Handspan project where she initially gained community and council support and then a working group took on the project. The pamphlet suggests that the citizens would recognize each other through the qualities described above, but that "most of them will never physically" meet. ${ }^{121}$ Again this is confirmed by PTU co-workers. Even after 15 years of a close working relationship, Spellings and Brooke have never met in person, due to geographic distance. Readers of MTM are likewise described as "unknown friends," supporting the inclusive belief of connecting across borders and culture to which the publication aspires.

As well as inspiring action for change, early readers of MTM, especially, saw networking communications as an action in itself. This highlights the importance of process to PTU and peace educators. Reardon holds that the learning process is much more important to education than meeting objectives or outcomes. Does this apply to education for activism in which communication itself is considered essential action?

\section{Education as worldview transformation}

Above, I have foregrounded the voices of peace workers who contribute to MTM. I now examines the ideas raised in relation to these voices by bringing them into conversation with the peace education theorists introduced above: Reardon, Danesh and Salomon. ${ }^{122}$ The visions and views expressed on the

\footnotetext{
118 Gita Brooke, ed., “Neve Shalom/Wahat Al-Salam,” Many to Many, no. 25 (September 1988): 5.

${ }^{119}$ Gita Brooke, ed., "Neve Shalom/Wahat Al-Salam - a Community of Peace Working for Arab-Jewish Coexistence and Cooperation - Struggles to Assure Its Future," Many to Many, no. 63 (March 1998): 10-11. 120 Brooke, "Towards Peace Through Unity."

121 Ibid.

122 Reardon, Comprehensive Peace Education: Educating for Global Responsibility; Danesh, "Towards an Integrative Theory of Peace Education"; Salomon, Peace Education.
} 
pages of MTM are affirmed by the academic literature on the subject of peace education. A culture of peace is most discussed in academia in the context of peace education. Similar to the perspectives of MTM readers, the visions of peace educators are broad and holistic. Salomon identifies the three main types of peace education programs as designed to: 1 ) understand the other's humanity; 2) develop general knowledge about conflict, violence and war; and 3) to cultivate non-violent behaviour and conflict resolution skills. ${ }^{123}$ He notes that most programs contain elements of all three. ${ }^{124}$

The first kind of peace education, cultivating mutual understanding, is often used in helping specific groups in conflict relate to each other, as in Israel/Palestine at the School of Peace in Wahat Al-Salam/Neve Shalom. Danesh designed the Education for Peace curriculum as a program for schools in Bosnia/Herzegovina based on the Integrative Theory of Peace. ${ }^{125}$ For Danesh, a culture of peace is one of four prerequisites for effective education for peace, prerequisites that also describe the outcomes of effective education for peace. ${ }^{126}$

As an example of the second kind, Salomon gives the program at Teacher's College, Columbia University, "that attempts to prepare students for active and responsible citizenship by developing their critical thinking, inquiry, and reflective skills." ${ }^{127}$ Reardon founded the peace education program at the Teachers College, Columbia University, and lays out a vision for a comprehensive peace education curriculum in her book of the same name. ${ }^{128}$ For Reardon, enabling the capacity of learners to form a culture of peace, rather than continuing in a culture of violence, is the overall purpose of peace education. Even with this classification in mind, the types of peace education practised and theorised by Reardon and Danesh evade narrow definitions in order to address the problem of violence in human relationships in all its forms. Danesh and Reardon advocate complete transformation of the current ways of thinking and interdependent structures, as does PTU. Reardon discusses the limitations of the either-or mentality and argues that we need peace education that accepts complexity, based on the core values of planetary stewardship, global citizenship and humane relationship. ${ }^{129}$ She thoroughly critiques the dominant mode of education in the United States at the time suggesting it must be completely transformed in order to change a culture of war to one of peace.

\footnotetext{
123 Salomon, Peace Education. 107.

124 Ibid.

125 Danesh, "Towards an Integrative Theory of Peace Education."

126 Ibid.

127 Salomon, Peace Education. 107.

128 Reardon, Comprehensive Peace Education: Educating for Global Responsibility.

129 Ibid., 59.
} 
The third kind of peace education focused on skills and behaviour is also addressed by the approaches of Danesh and Reardon. Salomon highlights the importance of context to peace education. He focuses on peace education in the context of intractable conflict, the condition he argues peace education was developed to deal with originally, and the context he views as specifically addressed by UN calls to solve the root causes of conflict. ${ }^{130}$ Salomon's empirical research on the limitations to peace education is drawn from the ongoing conflict between Israel and Palestine. Like Reardon and Danesh, Salomon also discusses the design of peace education to change students thinking, this time phrased as rewriting the collective narrative. Accordingly, he says, "delegitimization and dehumanization are the key to understanding what peace education in the context of intractable context is supposed to be about: It is about learning to legitimize the collective narrative of the other side and to humanize it." ${ }^{131}$

The collective narrative shaping the dominant worldview is often tied to material power. Salomon gives the example of peace education in Israel/Palestine in which he found Israelis were more likely to change their narrative of Palestinians while Palestinians, who have less material resources, held more tightly to their narrative of Israelis. Like Danesh and Reardon, Salomon acknowledges the transformative potential of peace education, but he is much more realistic about the difficulty and challenges of the process. Progress made in workshops is often undone very quickly by the context of conflict. "One ought to aim at good enough peace education ... not to try the impossible," says Salomon. ${ }^{132}$ Is a culture of peace the impossible?

The purposes and values proposed and practised by the above scholars have a lot in common with PTU's understanding of the importance of education to a culture of peace. In 'Towards PTU,' the "ordinary citizen of goodwill" is described as becoming "educated in a true sense of world citizenship and responsibility," a process of realization by which he, "earnestly seeks ways to play his part from a standpoint of identification with and loyalty to his highest vision of what it means to be human and to serve the well-being of all planetary life." ${ }^{133}$ Education in world citizenship and responsibility, concepts to be discussed in a coming chapter, leads to a sense of oneness with humanity and actions that align with the ideal of what it means to be fully human. The form of action is service, not limited to human society but the earth and its creatures. This vision could very well be summed up by the core values of

\footnotetext{
130 Salomon, Peace Education, 109.

131 Salomon, Peace Education., 111.

132 Ibid., 114.

133 Brooke, "Towards Peace Through Unity."
} 
Reardon's peace education curriculum: planetary stewardship, global citizenship and humane relationship. ${ }^{134}$

The role of education for PTU, particularly some types of peace education, is to develop a 'sense' of 'world citizenship' and 'responsibility' arising out of a place of goodwill. This sense will encourage the citizen to reach for an ideal through their actions and service for 'all life.' World citizenship or global citizenship is a common element of peace education curricula designed to foster a sense of being part of an interdependent humanity. The repetition of 'sense' suggests that education involves feeling and emotive capacities as well as rational thought, another point of importance to peace educators. The role of education in forming 'world citizens' concerned for their planet and acting in a human rights framework expressed by PTU is similar to peace education curriculum and UNESCO documents. Article four of the UN Declaration and Programme of Action for a Culture of Peace gives particular importance to education, stating, "Education at all levels is one of the principal means to build a culture of peace. In this context, human rights education is of particular importance."135

While it is inclusive of a range of perspectives on peace, it also frames and suggests a worldview through which to approach a culture of peace. To consider how it does this, evidence of the discourse of a 'culture of peace' and/or education is drawn largely from MTM phase two. While PTU has always been focused on forming a culture of peace, as seen in evidence drawn from other phases of MTM, the conception of 'a culture of peace' in relation to education became clearer after the Year $2000 .{ }^{136}$ Discourse on a particular topic increases when it is profiled by UNESCO, the educational arm of the United Nations. The first decade of the new millennium was dedicated to a Culture of Peace and NonViolence for the Children of the World (2000-2010) by the UN. ${ }^{137}$ A range of initiatives on a culture of peace by UNESCO appear on the pages of MTM during phase two. A 'culture of peace' as a discourse gave renewed focus to Peace Through Unity even though they had always been working for a culture of peace before the General Assembly gave it legitimacy and backing through The Declaration on a Culture of Peace in 1999. ${ }^{138}$ That the UN would profile a culture of peace shows that an area of

\footnotetext{
${ }^{134}$ Reardon, Comprehensive Peace Education: Educating for Global Responsibility. 59.

135 United Nations Declaration and Programme of Action on a Culture of Peace.

${ }^{136}$ Issue Numbers that have articles/editorials specifically on a 'culture of peace,' 1998 - 2005:

$64-69,71,72,74,75,76,77,79,80,81,82,83,84,85,87,89,90,93$.

${ }^{137}$ Brooke, Wanganui Culture of Peace 2002.

138 United Nations Declaration and Programme of Action on a Culture of Peace.
} 
agreement was forming in civil society and at the UN on its importance. ${ }^{139}$ It also gives good reason for educators to focus on a culture of peace as a body of knowledge develops on it. The theme for the International Day of Peace 2013 was 'education for peace. ${ }^{140}$ Commemorative years gave direction to PTU for the focus of MTM, though its enclosures always covered a range of issues.

Examples of MTM contributors responding to each other across the pages are evident in 'Building a Culture of Peace and the Evolution of Consciousness.' ${ }^{141}$ The article is a summary of a seminar held at the UN headquarters in NYC given the above title, likely written by Iris Spellings who was also a keynote speaker and regular contributor to MTM. The report finished by inviting MTM readers to respond to the questions posed at the seminar on a culture of peace. In the December 2004 issue, two readers David Kimball and Helen Huber, answered by describing their vision of a culture of peace and what they were doing personally to promote it. ${ }^{142}$

David Kimball's thinking was sparked by the American invasion of Iraq, and writes, "Because I didn't want to just say, 'Our present Administration was wrong,' I came up with my own list of four areas: 1) critical analysis; 2)Empathy; 3)Ethics/Justice; and 4) Conflict Management." ${ }^{143}$ Kimball realized these categories apply to macro level and intrapersonal and ties it to the quality of empathy, "If we learned to empathize more, we would have less interpersonal abuse." ${ }^{144}$ Kimball's four areas echo the types of peace education identified by Salomon; where empathy stands for understanding the other's humanity, and critical analysis and ethics/justice for general education on peace, and conflict management the same. Kimball's change of mind-set effected how he practised a culture of peace in his life: "This became, for me, my Culture of Peace. If I do anything locally or globally to stimulate or generate others to practice critical analysis, to learn/teach empathy, to consider ethics and justice, or to exercise conflict management, I am promoting a Culture of Peace." ${ }^{145}$ His letter sign-off, "I find the opportunities boundless," reveals his optimism for the work ahead. ${ }^{146}$

\footnotetext{
${ }^{139}$ For example, see "Appendix 1: UNESCO Publications on a Culture of Peace," accessed March 30, 2016, http://www.culture-of-peace.info/annexes/resA-53-370/pages42-49.html.

${ }^{140}$ Gita Brooke, ed., "Education for Peace," Many to Many, no. 124 (June 2013).

141 "Building a Culture of Peace and the Evolution of Consciousness," Many to Many, no. 89 (September 2004): 3-4.

142 Huber and Kimball, "Building a Culture of Peace and the Evolution of Consciousness - Responses."

143 Ibid., 13.

144 Ibid.

145 Ibid.

146 Ibid.
} 
Helen Huber's vision draws in the material culture of peace made evident through the arts. She says, "My vision of a Culture of Peace includes individuals creating beauty for one another and through the process of beauty making, becoming more and more cultured and civilized. Thus forming the basis for a peaceful society." ${ }^{147}$ The association between 'high culture and the civilizing process' has been troubled by post-colonial scholars. Huber's vision can be interpreted in relation to ideas about art and human development, that beautiful art/culture lifts our consciousness to a more mature place, in a similar sense to Nicolas Roerich. Huber invites readers to contribute to Help the Arts Reach Peace (HARP), another initiative by an ordinary citizen for a culture of peace. ${ }^{148}$ Huber is a long-term reader of MTM, evident in that she also contributed to the December, 1988 issue. ${ }^{149}$ Huber's (1988) letter mentions she is "networking 4 items," showing that MTM was successful in spreading information beyond its immediate network. ${ }^{150}$ Huber also responds to the Brooke's request for an update on her work, indicating the letter was elicited through personal correspondence, and describes her part in a Quaker environmental movement. ${ }^{151}$ The responses from Kimball and Huber are just two examples of readers sharing similar worldviews to PTU, indicative of an area of mutual agreement across the pages of MTM.

Outside of MTM, there is objection to Brooke's viewpoint in the letters to the editor of the Wanganui Chronicle. This garners a different readership that share a geographical location rather than a collective vision. The editorial of MTM March 1991 on the Gulf War was first published as a letter to the editor in the Wanganui Chronicle. ${ }^{152}$ Brooke questions why billions of dollars are spent on warfare when it is hard to secure funds to alleviate hunger and poverty. ${ }^{153}$ She uses the metaphor of a 'Holy War' as a call to the people of the world "to rise... and unitedly declare a holy war on those qualities and values that cause war."154 Another reader, signed only as Theo, replies in criticism to Brooke's "idealistic letter," and fails "to get" the metaphor. ${ }^{155}$ Brooke replies and passionately, but gently, corrects Theo's interpretation of Brooke's call for "unity." ${ }^{156}$ Theo responds with a final word in which

\footnotetext{
147 Ibid., 14.

148 Ibid.

149 Helen Huber, “Letter XIII,” Many to Many, no. 26 (December 1988): 13.

150 lbid.

151 Ibid.

152 Gita Brooke, "The Gulf War," Wanganui Chronicle, February 15, 1991, sec. Letters.

153 lbid.

154 Ibid.

155 Theo, "Peace and War," Wanganui Chronicle, February 22, 1991, sec. Letters.

156 Gita Brooke, “Unity Worth Working for," Wanganui Chronicle, February 27, 1991, sec. Letters.
} 
he "deprecates her way of going about [peaceful action]," and condones he US invasion of Kuwait. ${ }^{157}$ Brooke makes her own final comment the following week to affirm the need for "goodwill on fire" in all relationships. ${ }^{158}$ Goodwill, or faith, is exactly what Theo does not offer as a reader of Gita's vision. An area of mutual agreement could not be established in the Chronicle as the two writers cannot find a starting point of understanding. Instead of analysing Theo's letter point by point to disprove his assertions, Brooke tries to clarify her own, based on his interpretation. This reflects Brooke practising a mode of communication attempting to create an area of mutual agreement in that she does not attack and defend in argument or make personal accusations.

The disagreement across the letters to the editor speaks to the difficulty of creating an area of mutual agreement as a learning environment. Two individuals in conflict cannot be forced to look for their similarities in order to increase understanding and move to solutions. Rather it is a process that relies on individual goodwill. Warranted, the belief in the necessity of unity and the oneness of humanity is a worldview, however one more conducive to a culture of peace.

As peace educators attest, transforming worldviews through education is very difficult. Worldviews are deeply engrained and reinforced by the socio-political context in which education takes place. Salomon notes that the attitudes that peace education changes are often those not deeply held and most likely to revert back. Solomon expresses the difficulty of the task when he says, "That which peace education attempts to do in contexts of conflict is to an extent a subversive activity..., challenging the commonly held, dominant collective narrative and trying to establish a new, more accepting and tolerant one. A battle thus ensues between the strong, dominant narrative widely held by society at large and the newly born one, held by but a few. Little wonder that its chances of surviving in the face of the collectively held narrative are not very good."159 This is why Danesh states that the most effective education for peace takes place within a culture of peace.

Danesh and Salomon also discuss the role of structure in education for peace and the effectiveness of changing patterns of thought. Based on experience with Education for Peace curriculum, Danesh notes that it is difficult to educate for peace in a culture of war and violence because the issues of peace will seem "unrealistic or not applicable to realities of life." 160 Danesh

\footnotetext{
157 Theo, "Interesting Points," Wanganui Chronicle, March 5, 1991, sec. Letters.

158 Gita Brooke, "The Burning Issue," Wanganui Chronicle, March 14, 1991, sec. Letters.

159 Salomon, Peace Education, 115.

160 Danesh, "Towards an Integrative Theory of Peace Education," 60.
} 
observes that, "the discrepancy between theory and practice always has a detrimental impact on student's learning processes as it places them in a state of conflict between what is said and what is done."161 In the context of wider political structures upholding elements in intractable conflict, Salomon notes the subversive nature of peace education and the likelihood the learning will fade without reinforcement. It is very difficult to change attitudes and convictions in situations of conflict. Convictions deeply held are very difficult to change. Salomon's empirical "findings do not suggest that centrally held attitudes cannot be changed by peace education, but they do suggest that changing them is exceedingly difficult and rare. Whether changes in more peripheral attitudes can lead to changes in the more central ones is still an open-ended question." ${ }^{162}$

MTM is part of a wider landscape of educational activities and learning processes for a culture of peace. It furthers unitive relationships and worldviews in an area of mutual agreement, and as inspiration for what individuals can do, some of which may already be developing a unity-worldview and looking for ways to express it, as readers such as Kimball and Huber have. MTM is a deterritorialized publication situated in a shared language rather than a shared place. The political implications of language use, particularly that coming from a spiritual worldview, is discussed in the next chapter.

${ }^{161}$ Ibid.

${ }^{162}$ Salomon, Peace Education, 116. 


\section{Chapter 3: Transformation}

"It is a truism to say that we live in a time of unprecedented change and transformation. Yet it is only by keeping this fact continually in the forefront of our minds that we can avoid the trap of imagining that we can be exempted from active personal participation in and co-responsibility for the immense changes which must affect radically the lives of every one of us."163

\section{The spiritual underpinnings of PTU's vision}

The overall transformation that PTU is working towards can be viewed as changing a culture of war to a culture of peace. As shown in the previous chapter, education is integral to this all-encompassing process through the potential for worldview transformation. This chapter further examines the process of changing patterns of thought and societal structures to that of a culture of peace in a 'time of unprecedented change and transformation.' As outlined in the previous chapter, peace education aims to transform mind-sets to 'unity-worldviews.' The concept of mind-set or worldview is also known as consciousness, a well-used word in MTM used in a similar sense to spirit. The concept of consciousness is drawn on to explore the spiritual vision of PTU. Spirituality provides an inner reference point for external realities. Consciousness transformation is the internal process that is bridged by the concept of peace to the external processes of political and economic transformation. However, transformation begs a deeper change, a radical undoing and recreating of the current internal and external structures. For PTU, change and transformation witnessed externally begins within individuals who have the power to change their mind-sets so effect changes in behaviour to eventually form a culture of peace.

In this chapter, I stress the importance of process to the activities of PTU and the binary between thought and action is troubled. Building on the previous chapter, the main point is that thought-work can be a kind of spiritual-work, expressed/embodied most vividly in the process of communication, and can be considered a form of action. This will lead to the next chapter which teases the question of whether it is the only form of feasible action for PTU to take in the current structure of nation-states.

\footnotetext{
${ }^{163}$ Brooke, "Towards Peace Through Unity."
} 
The vision of 'Towards Peace Through Unity' finishes by offering seven points which might serve as the basis for an area of mutual agreement. ${ }^{164}$ These points are an essential starting point for a discussion of the spiritual underpinnings of PTU's vision. The seven points are progressive and build on each other. They are inclusive and intended to further the building of relationships through an area of mutual agreement. ${ }^{165}$ This chapter introduces them point by point as if introducing the dogma of a particular religion and give examples to ground them in the work of PTU. The spiritual underpinnings of PTU address the problematic of unity introduced in the previous chapter: how to address difference. PTU holds a vision for 'unity in spirit' that transcends external differences. The convictions expressed by the seven points remain central to PTU's work, although they found expression in different forms over the years.

One of the first things Gita and Anthony Brooke did when they began the ten years of travel was write 'Towards Peace Through Unity,' which outlines the vision of PTU. ${ }^{166}$ It was written in collaboration on the road with a group of Danish youth working for social justice who came to meet with the Brookes. ${ }^{167}$ The Danish youth asked the Brookes to present the seven points of the pamphlet to a gathering of people from many religious, faith-based and secular societies. Even though there were disagreements between, for example, a scientologist and a Catholic, an atmosphere was created by the host that kept them in the room. ${ }^{168}$ The group tore the seven points to bits and then, one by one, put them back together again with only one word changed. ${ }^{169}$ Brooke described the writing of the pamphlet as a learning process for all. ${ }^{170}$ Some of the participants then invited PTU to present the seven points at an exhibition, in which they were blown up into a banner that took up a whole wall. ${ }^{171}$

The spiritual vision of PTU was thus formulated and presented in an inclusive way to a range of religious and secular people. This suggests why the language is broad and ambiguous in some places as it is designed to include all people. The process of writing the pamphlet emphasized to Gita Brooke the importance of timing. ${ }^{172}$ The rest of their travels were guided by a kind of spiritual compass rather than strict planning to meet dates and deadlines. While the Brookes actively sought out crisis points in

\footnotetext{
164 Ibid.

165 Ibid.

166 Ibid.

167 Brooke, Interview 2.

168 Ibid.

169 Ibid.

170 lbid.

171 Ibid.

172 Ibid.
} 
the world, as places most indicative of change and transformation, they did not force anything but waited until doors opened to them. The story of the pamphlet's origin is indicative of the importance of process in the formation of the expression of unity. The seven points are not so much objectives or endpoints, but general shared beliefs to further an ongoing process.

The pamphlet, 'Towards Peace through Unity,' offers a general prediction of societal change towards a culture of peace as a kind of evolutionary process, comparable to human development. Cultural formation is envisioned as a dynamic, creative process of multiple practices and relationships. The spiritual outlook, comprised of complex thinking and feeling capacities, is similarly characterized as in flux as it strives for maturation and finally "perfection." ${ }^{173}$ In conversation, Brooke uses the metaphor of a waterfall for this outlook. ${ }^{174}$ Constantly falling, no point you see remains the same. To take a photo is to capture a split second that does not exist the moment after the shutter closes. Brooke describes a way of thinking based on heart as a way to see the whole movement, rather than head thinking that takes a static snapshot. ${ }^{175}$ Analytical thinking necessarily compartmentalizes knowledge while 'heart thinking' seeks holistic understanding. As evident in the quote preceding this chapter, the language of PTU is abstract and filled with truisms that gain traction and meaning when filtered through the organization's publications, the founder's words, and thoughts translated into actions.

In the context of the post-WWII and the nuclear arms race of the Cold War, that one was living in a time of unprecedented change would have been a truism. This was a time politically in which many changes occurred - states transformed and built whole regimes only to collapse. Mary Kaldor, affirms PTU's pronouncement at the 'end' of the Cold War period in The Imaginary War when she states, "This is a time of political spontaneity, when real choices can be made about the future. It is a time of fluidity, when established political alignments are breaking down, when new ideas expressed by individuals, social movements, political factions, etc. can really influence the situation." ${ }^{176}$ Hope is the main value this time of change offered to social movements, leading PTU to adopt the motto, 'A strategy of hope for a world in crisis. ${ }^{177}$ That it is a time of change offers the hope and possibility of reconstructing a better world. ${ }^{178}$

\footnotetext{
173 Brooke, "Towards Peace Through Unity."

174 Brooke, Interview 3.

175 Ibid.

${ }^{176}$ Mary Kaldor, "Introduction," in The Imaginary War: Understanding the East-West Conflict (Oxford: Oxford, 1990), 3-8.

177 See Many to Many issues in Phase 2

178 'strategy of hope for a world in crisis'
} 
Kaldor describes the Cold War as an 'imaginary war' which relied on a hegemonic culture of war that thought and behaved as if the "second world war had never really ended." 179 The dominant culture actively prepared for war through the accumulation of weapons and in the discourse of defense from threat of East/West. It is interesting that Kaldor refers to the role of the imagination as it links to the idea of worldview transformation leading to cultural change. As a teenager in the 1940s, Gita Brooke described a similar process of the Second World War continuing in a different form, when she said, "The war didn't end - it went underground, into the human psyche." ${ }^{180}$ Worldview transformation within each individual is essential in changing the dominant culture of war, as how we think affects how we act.

\section{Grounding the seven points of 'Towards Peace Through Unity'}

This section shows how the seven points of 'Towards PTU' find expression through MTM and the work of PTU as a UN accredited NGO. The political content of MTM is framed in spiritual thoughtfulness by the editorials written by Brooke and the prayer The Great Invocation. Brooke's editorials began as a letter prefacing the letters in Phase one and two, then in Phase three were named as Editorials beginning March 2000. The editorials in Phase four of MTM in particular are beautiful expressions of Gita's outlook on life, connecting philosophical ideas with the work of the UN. As previously outlined, the content of Phase three and four of MTM is largely UN sourced, reflecting the importance of the activities and agencies of the massive organization.

The first point states the existence of "an invisible, harmonizing energy at work throughout the universe." ${ }^{181}$ This could refer to the existence of God. In a more nebulous sense, it could refer to a shared world consciousness or global mind. Point one addresses the problem of unity as it states that this energy, "can affect our decision-making in the highest interest of all, if we freely decide to attune to it with the will to think and act in the interests of the whole." ${ }^{182}$ The problem of unity is solved by the trust in a world-embracing energy, which enables us to think and act for the good of all people, as

\footnotetext{
179 Kaldor, "Introduction."

180 Brooke, Interview 1.

181 Brooke, "Towards Peace Through Unity."

182 Ibid.
} 
it enables us to comprehend what is outside our limited consciousness. It implies a unity of spirit that transcends external differences.

The language used in 'Towards Peace Through Unity' is inflected by New Age discourse. New Age is an umbrella term for a range of alternative spiritual beliefs, groups and practices that have arisen since the early $20^{\text {th }}$ century. Brooke and some PTU co-workers draw on the work of Alice Bailey, a prolific author on esoteric philosophy, from whom many Theosophical and New Age groups later drew insight. However, Brooke does not identify as 'new age.' Bailey was influenced by the concepts of oneness and consciousness present in Eastern religions such as Buddhism and Hinduism. Brooke combines esoteric philosophical discourse with that of the liberal cosmopolitanism of the UN. These blend with her own idiosyncrasies of speech, such as very long sentences and the tendency to make adjectives into nouns through the suffix 'ness,' such as 'livingness.' The result is a unique formulation through language of an expression of Brooke's own spiritual convictions for a new civilization, communicated as a kind of narrative in the editorials of MTM. The content of MTM which is concerned with international relations is framed by a spiritual worldview. Phase two onwards, issues begin with an editorial and end with the prayer, 'the Great Invocation.' PTU frame the contents focused in political activities and events in spiritual thoughtfulness, and so the structure of MTM echoes the spiritual vision of MTM as all things interconnected as one.

Point two affirms that it is, "desirable to identify our own power of will with this unifying power," and "to be open to whatever disciplines and teachings" help one to "maintain identification" with the higher power. ${ }^{183}$ Again, a position of commonality and inclusiveness is taken to faith and religion. The Great Invocation, a prayer published at the end of each issue of MTM expresses the seven points of PTU's vision in condensed poetic form. According to the Lucis trust, it was given to Alice Bailey in 1945 for all "people of goodwill," and contains truths seen to be held by all faith-based groups. ${ }^{184}$ The prayer expresses its relevance to 'all people,' and was published in different languages across the issues of MTM to show its inclusivity, including Te Reo Maori, Hebrew and Serbian.

Point three holds that, "This invisible creative energy embodies what might humanly be interpreted as a purpose for the infinite unfoldment and evolution of all life."185 The UN is treated as a

\footnotetext{
183 Ibid.

184 "Alice Bailey Books | Books \& Publications Store (Lucis Trust)," accessed March 30, 2016, https://www.lucistrust.org/store/category/alice_bailey_books_p.

185 Brooke, "Towards Peace Through Unity."
} 
powerful centre for humanity, a central point for the focusing of unitive energies. Unity is interpreted in a spiritual sense as unity-in-spirit made manifest in the work of the UN for all people. The preamble to the UN Charter, 'we, the peoples...,' is interpreted as including every individual on the planet. ${ }^{186}$ The individual responsibility to recognize ones role in the unitive work of the UN will be further discussed in regard to the citizen of goodwill in the next chapter. PTU is not unique in treating the UN as a spiritual centre. Again it is part of a network of like-minded individuals, organizations and trusts working for similar purposes. PTU co-worker, Steve Nation, works for World Goodwill which publishes material and programs under the banner of the Lucis Trust. ${ }^{187}$ The Lucis Trust has Consultative Status with the Economic and Social Council of the United Nations (ECOSOC) and World Goodwill is recognized by the Department of Public Information at the United Nations as a NGO. ${ }^{188}$ Unsurprisingly, World Goodwill is a regular contributor to MTM and has also published its own small newsletter since $1995 .{ }^{189}$ Evidently PTU is part of wider spiritual networks, expressed in print publications and positioned as bound up with the UN, concerned with international relations.

The UN may not be the higher unifying power or consciousness, but it could be taken as evidence of its existence. The United Nations is considered a 'powerful centre of humanity' by PTU. It contains the hope that through one institution, humanity can be united in shared purpose and vision for the future. As expressed by PTU co-worker Spellings, "The United Nations has been referred to as the hope of humanity, as 'humanity's most far-sighted and significant undertaking'. It represents the fact of our oneness-a reflection of, perhaps, the highest achievement in consciousness marked by humankind as a whole at this time." 190

The various resolutions, declarations and plans of action written by the UN General Assembly can be seen as plans for the unfoldment and evolution of life. As an expression of the purpose of the United Nations, the preamble to the UN charter is held with the reverence accorded to religious texts by PTU and other civil society movements. In a presentation Brooke gave to the UNANZ in Wellington on the United Nations and a New World Order, she describes the preamble to the Charter, saying,

\footnotetext{
${ }^{186}$ Charter of the United Nations, 1945, http://www.un.org/en/sections/un-charter/preamble/index.html.

187 "About World Goodwill - World Goodwill (Lucis Trust)," accessed February 10, 2016, https://www.lucistrust.org/world_goodwill/about_wg.

188 "Support of the United Nations (Lucis Trust)," accessed February 10, 2016, https://www.lucistrust.org/about_us/support_un.

189 "Newsletter," World Goodwill, 1995.

190 Iris Spellings, "We the Peoples: The Culture of Peace \& Fulfilling the Mission of the United Nations," ed. Gita Brooke, Many to Many, no. 124 (June 2013).
} 
"These words are eternally young and reflect the vision, wisdom and simplicity of ancient scriptures and sacred books." ${ }^{191}$ However, she says the rest of the Charter has aged and no longer has the same relevance, reflecting the need for reform of the UN organs. ${ }^{192}$ The spirit of the text is commonly referred to in the vision statement of MTM which offers, "In the spirit of the preamble to the charter of the United Nations, an instrument for the furthering of better relationships." ${ }^{193}$ Spellings suggests a triad of texts that guide the political work of PTU while imbued with a kind of religious significance: "Three UN documents that stand out in order of importance are: Charter of the United Nations; The Universal Declaration of Human Rights; and the landmark United Nations Declaration and Programme of Action on a Culture of Peace, which was adopted by consensus on 13 September 1999 by the UN General Assembly." ${ }^{\prime 194}$ While the Declaration and Programme of Action on a Culture of Peace does not have as widespread recognition as the Charter or Declaration of Human Rights, Page suggests that it is only a matter of time when he says, "it has taken some 50 years for the notion of universal human rights to gain widespread acceptance... it will take another 50 years for the notion of a culture of peace to gain widespread acceptance." 195 In any case, the above shows the power of print in the long process of cultural change.

The potential for all people to develop, perhaps towards living in a peaceful manner, is affirmed by point four: "there exists within every individual the capacity to evolve in and towards perfection." 196 Thinking of evolution as a purposeful process, perfection could be taken here to mean a utopic future. In the meantime one can develop their inner self through meditation and practices of service. The UN too has the potential to evolve to perfection, as if it were a living organism. The spiritual work of PTU is to make the UN more human, through the inclusion of the people's voice through NGOs, service and spiritual work. In 2004, PTU was one of the founding members of the NGO Committee on Spirituality, Values and Global Concerns-New York (CSVGC-NY), a Committee of the Conference of NGOs in Consultative Relationship (CONGO) with the United Nations. ${ }^{197}$ PTU representatives, Iris Spellings and Anne Creter co-chaired the Culture of Peace Working Group of CSVGC-NY for seven years. ${ }^{198}$ Spellings

\footnotetext{
191 Brooke, "Philosophical Reflections: The UN and a New World Order."

192 lbid.

193 See any cover page of any issue of MTM

194 Spellings, "We the Peoples: The Culture of Peace \& Fulfilling the Mission of the United Nations."

195 James S. Page, "The International Year for the Culture of Peace Was It Worthwhile?," International Journal of Cultural Studies 4, no. 3 (September 1, 2001): 351, doi:10.1177/136787790100400305.

196 Brooke, "Towards Peace Through Unity."

197 Spellings, Personal Communications.

198 Ibid.
} 
says, "Through these groups, PTU has organized meetings, UN DPI/NGO briefings and events, including the UN High Level Forum on the Culture of Peace for the past four years, and co-sponsored many other meetings at the UN and in the New York City area." 199 Additionally, PTU representatives Spellings, Nation and Sharon Deep are on the Council of the Spiritual Caucus at the United Nations. ${ }^{200}$ The Spiritual Caucus make space for stillness and silence at the UN Headquarters through regular meetings in the meditation room. "To sit in silence at the United Nations is to foster contemplation of the aims of the organization as expressed in the Charter." ${ }^{201}$ While many different faiths are present, they share common aspirations expressed through the charter. As well as written and spoken communication as a form of action, here silence is taken to be a form of action for furthering service to the UN. Silent reflection of the aims of the UN bridges the internal 'heart' and external politics.

Point five emphasizes the choice humanity can make as to how they live their lives. It suggests that the "disunity and conflict" and environmental pollution faced by humans is the result of a choice to "deviate from the recognition and attunement with" the "unifying energies." 202 The root causes of conflict and violence must be transformed, and in this vision, the root cause lie in the psyche of humans themselves. The core message is that the 'old mind-set' cannot lead to the radical change and transformation required for the creation of a culture of peace. The convictions expressed here underlie the editorials of MTM which repeat a narrative of the old civilization crumbling and making way for a new one. The editorials take shape over the decades of publication. Beginning with letters thanking contributors, they expand to express Gita and Anthony Brooke's hopes for the future and ethical direction for current crises. As expressed in 'Towards Peace Through Unity,' the intelligence responsible for creating the old world order cannot be expected to bring about the next. ${ }^{203}$ In other words, the mind-set of a culture of war cannot be expected to create a culture peace, unless it radically changes. Consciousness, as in awareness, of the pervasiveness of a culture of war and violence is considered by many activists as the first step to changing it. Reardon similarly highlights the importance of 'consciousness' which could also be termed 'worldview' or 'mindset' when she states that, "The general purpose of peace education ... is to promote the development of an authentic planetary consciousness that will enable us to function as global citizens and to transform the present human

\footnotetext{
199 Ibid.

200 "The Spiritual Caucus at the United Nations."

201 lbid.

202 Brooke, "Towards Peace Through Unity."

203 Ibid.
} 
condition by changing the social structures and patterns of thought that have created it." ${ }^{204}$ Thus, the vital role given to education and information sharing, as evidenced by MTM, to building a body of peace knowledge and increasing consciousness that way.

Consciousness is defined not only as awareness, but a deep spiritual sense of being connected to a whole organism of life, earth. The image taken of earth from space during the first space explorations profoundly changed the thinking of some in terms of global or holistic view of humanity. It was part of pre-existing discourse, usually from Eastern spiritual disciplines that stress holism, interconnection and interdependence of life, but it also diverged and met the discourse of cosmopolitanism/internationalism. The result is a universal view of life that seeks to include and account for the smallest particle to the largest galaxy. The spiritual underpinnings of PTU's vision are shared by many of the contributors to MTM. Repeated responses, particularly in phase one, iterate that sharing and networking information is action in itself. Not only does it inspire concrete action, it influences the global consciousness, a kind of world spirit.

As point six affirms, the deepening of "a sense of our invisible unity in spirit with all created life, and with the source of that life," draws "an ever greater capacity to serve in co-operation with our fellow human beings to establish right human relationships." ${ }^{205}$ Phase one of MTM in particular features the creative and thoughtful visions of individuals for peace. Marko Pogacnik describes and draws how he envisions the spiritual connections between readers of MTM, May 1983:

"May I join this collective meditation on peace through unity that is developing here. For me it is not just a collection of our common dreams but a powerful invocation in which our personal energies are strengthened by the earthly streams of energy emanating from the places from which our letters are coming and from those to which they are going.

Writeing [sic] this letter my feet are touching this holy earth, while reading it, others will be touching other spots all over the planet. While our feelings and thoughts will be pondering upon peace and unity, we shall in fact become peaceful, thus uniting our

\footnotetext{
${ }^{204}$ Reardon, Comprehensive Peace Education: Educating for Global Responsibility. X.

${ }^{205}$ Brooke, "Towards Peace Through Unity."
} 
points of the earth : all in all : a delicate but creative movement like this : may it be so."206

Even though the readers are geographically dispersed, in the act of reading the same text, their minds will be united in a sense, and through thinking about peace and unity, the readers themselves will become more peaceful. This is another way of expressing how the pages of MTM can form and enact an area of mutual agreement through networking. It grounds the concept of a shared global consciousness in the act of reading.

Point seven sums up by affirming "right relationships" will establish the foundations for "a true brotherhood of life and peace on earth." The above outlined spiritual convictions influence the course of political action taken by PTU. It suggests a way of living that can form a culture of peace through individual actions, although it is also a utopic text. The belief in a world consciousness or encompassing energy, the constant change and flux of life and the capacity for individual agency to choose unity instead of conflict with life are important. The language of the pamphlet reflects the idealist and abstract content. The editorials of MTM reiterate the same convictions in sometimes simpler language. It is a holistic vision for cooperation for a peaceful future.

The seven points of PTU's vision as the starting point for an area of mutual agreement have been iterated in various forms by other peace workers. Chapter 2 featured Joseph Abileah's vision of a "bridge to peace... built on four pillars."207 Pillar 2 is "the holiness of life," suggesting a spiritual framework for political action to preserve life. The four pillars express values similar to the seven points. The pillars are "fixed on either side of the abyss on two mighty rocks which are faith and hope." ${ }^{208}$ Abileah specifies that "faith must be in our fellow-human beings, faith in the human heart and in the divine spark which dwells in this heart." ${ }^{209}$ This understanding of faith is akin to the trust Brooke has in humans around the world to carry out a culture of peace. The human 'heart' is also important to Abileah as it is to PTU's vision. The heart stands for complex capacities for feeling and insight, more holistic in scope than analytical thinking, and so harder to define. The 'divine spark' is the immaterial shared quality of all people on earth, according to the Judeo- Christian worldview, that is the "soul breathed into us by the Creator together with his spirit... towards this we can aspire in

\footnotetext{
${ }^{206}$ See Appendix 5 for a copy of the letter from Marko Pogacnik, Many to Many, no. 4 (May 1983): 5.

207 Abileah, "The Bridge to Peace."

208 lbid.

209 Ibid.
} 
unity." ${ }^{210}$ That the basis for unity is spiritual in Abileah's vision is similar to PTU's vision of "our invisible unity in spirit with all created life." ${ }^{211}$ Life not death is affirmed by peace workers and educators, and shapes the metaphors they use in relation to their work.

The metaphor of a living body is drawn upon as a narrative grounded in the land, that applies as much to the United Nations. This image helps explain the unconventional structure of PTU as attempting to reflect a living, growing organism rather than fossilize in hierarchy and strict categorization. Brooke envisions a much more organic way of living as organisms not organizations:

"In the restructuring, one must hope and pray that the UN will resist old habits and not again gravitate towards becoming a heavily organized institution. Let us hope it will resemble more a living organism, developing with sensitivity and intelligence in accordance with the purpose described in the Preamble of its Charter; and organism, made up of a unity of single nations and peoples; with a nervous system registering the pains and needs, the failures and successes of all its parts; with a heart beating in concord with all living things, ensuring that no blockages are allowed to hinder the flow of essentials to all corners of the organism, and with a head where all strategies for the welfare and wellbeing of the whole are discussed with intelligence and farsightedness and decided upon in full view of the entire world society." ${ }^{212}$

The connections and sprawling system of nerves speaks to the image of a network envisioned by PTU and enacted through MTM.

PTU's inclusive vision to humanize institutions through a culture of heart, such as the UN, presents relationships based on mutual understanding as the way to achieve this. It is shared by the network of MTM readers, such as Abileah, who endeavour to act in accordance in their own lives. Relationships are the beginnings of transformation. PTU co-workers, such as Spellings, have found ways to work within the dominant structures of the UN even though their way of working as a structureless organization, more like an organism, does not fit the governance hierarchy.

\footnotetext{
210 lbid.

211 Brooke, "Towards Peace Through Unity."

212 Brooke, "Philosophical Reflections: The UN and a New World Order," 8.
} 


\section{The political implications of spirituality for the 'ordinary citizen'}

PTU's inclusive vision is congruent with recent stands of IR theory that question the rational pursuit of 'useful' knowledge in the quest for peace and justice. I would not be able to discuss the spiritual underpinnings of PTUs vision in the discipline of IR if not for the in-roads made by critical IR academics who pursue alternative sources of knowledge. As discussed above in relation to narrative politics, the conventional or mainstream way of knowing and judging in IR draws heavily on moral rationalism developed in the enlightenment, as critiqued in The Vulnerable Subject. ${ }^{213}$ A main critique is that the pursuit of rational knowledge often ignores the complex emotive and relational capacities part of being human. The human faculty of reason is prized above all else, rather than considered as part of a range of human faculties. But there are an increasing number of academics experimenting with narrative and questions conventional boundaries of knowledge, as evident in The Journal of Narrative Politics. Two scholars that have been particular influential in my project to articulate the vision of PTU are Elizabeth Dauphinée and Robbie Shilliam. I draw on their work as examples of alternative ways of cultivating knowledge in IR that is more inclusive of a range of human faculties.

Dauphinée's training in the discipline of IR, like the young academic in The Politics of Exile, gave her confidence in her "ability to order and classify the world." ${ }^{14}$ This is what Hutchings calls the "resolute confidence of moral theorists." ${ }^{215}$ Even the motives of war criminals could be known, guilt and innocence discerned. Dauphinée was studying the war in the former Yugoslavia and in the course of fieldwork, amidst all her preconceived ideas and research agenda, she was asked, "what expert are you?"216 Asked from outside the frame of her discipline, it could not be answered from within that frame. It implicated Dauphinée in the discursive violence emanating from the physical violence of war. The certainty and invulnerability of the moral judge was shaken, calling for a radical way change in the way she wrote. As Hutchings explains, "For Dauphinée, the shaking of the certainties of judgement elicits a demand for an extension and of intensification of the scholar, not the abandonment of the claim to authority in judgement." ${ }^{217}$ Realizing she did not know what she thought she did, or that what

\footnotetext{
213 Beattie and Schick, The Vulnerable Subject.

${ }^{214}$ Dauphinée, The Politics of Exile, 2.

${ }^{215}$ Hutchings, "A Place of Greater Safety? Securing Judgement in International Ethics."

216 Dauphinee, "The Ethics of Autoethnography," 802.

${ }^{217}$ Hutchings, "A Place of Greater Safety? Securing Judgement in International Ethics," 38.
} 
she knows what not so means thinking about the world in different ways more inclusive of uncertainty and vulnerability in human relationships.

Dauphinée is trying to identify through writing her own "complicity in the violence" she seeks to "understand" or "explain," the violence in which she as a scholar seeks to intervene with her "myriad of good intentions and envisioned liberal projects." ${ }^{218}$ This is a self-reflexive approach which situates that scholar in the place in which they study. They are not removed as impartial observers, but deeply embedded in the structures processes, lives, and events of which they speak. It is an approach critical of 'liberal' projects based on good intentions of which consequences cannot be foreseen and may cause harm despite, requiring the researcher to be vigilant of the ever present possibility of violence and exclusion.

Enlightenment moral rationalism has been critiqued alongside colonial projects of expansion that seek to accumulate useful knowledge while excluding ways of knowing deemed irrational. Shilliam offers another language and way of cultivating knowledge that draws on the spiritual hinterlands as a site of emancipation from dominant colonial frameworks and a way to reconnect people of Maori and African descent. Shilliam seeks to heal the segregation of people from land and language by retrieving knowledge from the spiritual hinterlands that were never colonized by Cook or Columbus, as a way to support connectivity between Maori and Africa through deep relation.

"Decolonial science seeks to repair colonial wounds binding back together peoples, lands, pasts, ancestors and spirits. Its greatest challenge is to bind back together the manifest and spiritual domains. For in the latter domain exist hinterlands that were never colonized by Cook and Columbus, and therein lie the supports of a global infrastructure of anti-colonial connectivity."219

To do this he turns to the mythical figures of Arcadian Hermes, Tane/Maui from Maori cosmology and Legba of West African cosmology. The segregating logic of colonialism is linked to the method of knowledge production in the social sciences, whereas 'decolonial science' seeks to heal. The task of 'binding together' speaks to the problem of unity and difference addressed the spiritual vision of PTU. Shilliam writes, "the binding skills of Tane/Maui do not seek to collapse domains but, rather to make

\footnotetext{
218 Dauphinee, "The Ethics of Autoethnography," 802.

${ }^{219}$ Shilliam, The Black Pacific: Anti-Colonial Struggles and Oceanic Connections, 13.
} 
their agents relatable and their energies traversable." ${ }^{220}$ The focus is on enabling agents to relate in a decentralized way despite distance and separation.

The purpose of The Black Pacific is to support the project of mana motuhake, selfdetermination, of Maori in Aotearoa. ${ }^{221}$ Knowledge cultivation is thus shown to be a political practice concerned with the distribution of resources and power. It is akin to the project of narrative politics in the awareness of dominant traditions of knowledge production and the drawing together of an alternative narrative. Both Dauphinée and Shilliam's projects draw on what Schick calls "education towards critical self-reflection," that seeks to recognize one's role in oppressive structures, including dominant forms of knowledge production. ${ }^{222}$ Instead of a colonial project of expansion through the accumulation of 'useful' knowledge, Shilliam suggests the metaphor of knowledge cultivation which requires the practitioner to "turn over and oxygenate the past" as if it were soil. ${ }^{223}$ The metaphor of gardening is drawn upon by peace movements also as an organic process focused on growth. This line of IR thinking embraces vulnerability and deep relation between segregated people.

Exploring the spiritual underpinnings of PTU's vision continues this line of IR theory as a way to cultivate knowledge of peace movements in Aotearoa NZ. Brooke describes the work of PTU, through their unconventional model, as an attempt to answer the question of personal complicity in structures that oppress. While the convictions expressed in the seven points have influenced PTU's work during their travels around the world, and in Aotearoa NZ, they have not led Brooke to adopt an insulated, invulnerable approach. Building inclusive relationships is the motivation for PTU's vision. The editorials of MTM call for the transformation of unjust structures from a moral standpoint. They do draw on what PTU see as universal truths. However, PTU's approach is not to privilege and accumulate 'useful' problem-solving knowledge, but to call for radical self-reflection on the part of individuals as part of a process of consciousness change towards more peaceful relations. Brooke suggests:

"Perhaps the old mindset has taken the vision as far as it can. Like seeds, the hopes and dreams; blueprints and guidelines for new world may have needed a season of gestation; a time for sinking into the nurturing depth of the human heart and here take

\footnotetext{
220 Ibid., 21.

${ }^{221}$ Ibid., 11.

${ }^{222}$ Kate Schick, “Unsettling Pedagogy: Recognition, Vulnerability and the International," in Recognition and Global Politics: Critical Encounters Between State and World, ed. Patrick Hayden and Kate Schick (Manchester: Manchester University Press, 2016), 33.

${ }^{223}$ Shilliam, The Black Pacific: Anti-Colonial Struggles and Oceanic Connections, 25.
} 
root and summon quality and substance, before growing and coming into full expression in the Aquarian Age."224

The role of knowledge cultivation to worldview transformation is expressed by Brooke in the above editorial. But it takes time and space to be realized. Brooke draws on the spiritual language and capacities as a source of knowledge and transformation, when she says, "The mind, infused with heart fire, is well equipped for transforming and renewing all relationships, and for building the structures, bridges and networks of the future world community." 225 The heart is a metaphor for expressing a more integrated vision for peace and politics. Brooke gives examples of structures of connectivity between people as bridges and networks, which are already evident in the work of PTU.

Alternative projects of knowledge cultivation focused on connecting people have informed my analysis of PTU. The approach and vision of PTU is vital to other peace movements, who may have become fragmented in the neoliberal context of market competition for funding and resources, as will be discussed in the next chapter. It is vital for future peace researchers seeking to learn from the lived experiences of peace networkers. It has been important for me to cultivate the knowledge of PTU in a way that complements the inclusivity and vulnerability of their unconventional approach, so as to minimize the possibilities of discursive violence. However, it is impossible to say everything, especially when dealing with such an extensive archive.

${ }^{224}$ Gita Brooke, “Editorial - Newness," Many to Many, no. 111 (March 2010): 2.

$225 \mathrm{Ibid}$. 


\title{
Chapter 4: Responsibility
}

\begin{abstract}
"... the time has come when greater recognition and encouragement needs to be given by national governments to the indispensable contribution to a just and peaceful world that can potentially be made by the "common man" - the ordinary citizen of goodwill in every country..."226
\end{abstract}

\section{Taking responsibility: responding to calls to action}

With such a broad vision of peace, where does PTU direct the focus of their activities? The focus of PTU, at its most simple, is the individual, the 'ordinary citizen of goodwill,' a global citizen, who becomes many as 'we, the peoples of the United Nations.' The individual is the starting point to action at all levels; be it self-governance, local-governance, national-governance or supranational governance, depending on the context of what they are trying to achieve. These are all units of responsibility comprised of individuals. The first third of 'Towards Peace Through Unity' describes the 'ordinary citizen of goodwill' at work 'in every country.'227 It is the work of these citizens that PTU recognizes as crucial to "the cause of peace and justice." ${ }^{228}$ As Gita confirms in conversation, PTU has always been focused on the individual and the part they play in wider communities. ${ }^{229}$ These individuals, the 'ordinary citizens of goodwill' are described as a kind of archetype of peace workers, who Locke would describe as 'peace people. ${ }^{\text {'230 }}$ Their qualities include a "compassionate and inclusive outlook," a "selfless" way of living, a commitment to "humanitarian service" and a concern to expand "areas of mutual understanding." 231 The quality of 'goodwill' is akin to faith, a spiritual orientation that motivates service, as discussed in the previous Chapter.

This chapter continues from the previous chapter's discussion of the citizen of goodwill as educated in global citizenship and responsibility. It follows on from my questioning of thought and action as distinct. What is a global citizen and what are they responsible for? Why and how are they responsible? Of particular interest is whether and how individuals can be responsible or accountable

\footnotetext{
${ }^{226}$ Brooke, "Towards Peace Through Unity."

227 Ibid.

228 lbid.

${ }^{229}$ Brooke, Interview 2.

230 Locke, Peace People: A History of Peace Activities in New Zealand.

231 Brooke, "Towards Peace Through Unity."
} 
for UN calls to action in the form of print declarations or resolutions. The term 'global citizen' is used by PTU in the sense of a type of worldview, rather than in a strict legal sense. To have a worldview of a global citizen is to see yourself as connected to more than your immediate, material surroundings. In Cultivating Humanity, Martha Nussbaum gives a stern and relaxed version world citizen in the classical sense: "The sterner, more exigent version is the ideal of a citizen whose primary loyalty is to human beings the world over, and whose national local, and varied group loyalties are considered distinctly secondary." 232 The more relaxed version "allows a variety of different views about what our priorities should be but says that, however we order our varied loyalties, we should still be sure that we recognize the worth of human life wherever it occurs and see ourselves as bound by common human abilities and problems to people who lie at a great distance from us." ${ }^{233}$ PTU's primary loyalty is to human beings the world over, however, this identification with common humanity begins at home, in Whanganui, suggesting they adopt the more relaxed conception.

I explore the responsibility of an 'ordinary citizen of goodwill' to fashion an area of mutual agreement locally, in accordance with UN calls to action. I considers how citizens can respond individually and collectively to calls for action while negotiating the structure of the international, the limitations of multiple agendas and relations of power evident in the distribution of resources. While communication can be considered a form of action, there is still a desire on the part of NGOs for more concrete or material forms of action. This desire is often redirected to the local level of NGO work, where they have more capacity to effect change. PTU's unconventional structure raises opportunities and challenges to their work for a culture of peace as seen in two local projects. The Handspan Sculpture project in Whanganui, Aotearoa NZ, 2002, exemplifies the opportunities while the International Day of Peace, Wellington, Aotearoa NZ, 2015, shows the difficulties and challenges.

\section{Limitations to acting as global citizens}

Global citizenship refers to the expansion of the moral rather than the political boundaries of community. In other words, to be a global citizen does not require one world government but rather the sense of being part of transnational civil society. The interconnectedness of global justice issues

\footnotetext{
${ }^{232}$ Martha C. Nussbaum, Cultivating Humanity: A Classical Defense of Reform in Liberal Education (United States of America: Harvard University Press, 1997), 9.

${ }^{233}$ Ibid.
} 
requires a global response, by a shared moral community. Andrew Linklater describes the attraction of global or world citizenship in a way that makes sense with the context of PTU:

"Earlier anxieties about nuclear war, and contemporary anxieties about the risk that environmental devastation poses to human species and to unborn generations, have engendered a deeper sense of personal responsibility for the fate of the earth along with greater support for social movements and non-governmental organisations in a world that is still largely dominated by nation-states. For many, the attraction of world citizenship is its appeal to individuals to demonstrate moral concern and individual responsibility for the future of the planet in light of growing doubts about the efficacy of the territorial nation-state." ${ }^{234}$

Even though nation-states remain the defining political units of the international system, there is a growing disillusionment with their effectiveness to adequately address transnational environmental crises and other issues. Identification as world citizens enables people, such as the readers of $M T M$, to take personal responsibility regardless of the territory in which they reside.

A burgeoning global civil society expands democracy beyond the limits of the nation-state. Referring to the Stoic understanding of world citizenship, Nussbaum suggests, "we should give our first allegiance to no mere form of government, no temporal power, but to the moral community made up by the humanity of all human beings." 235 This moral community is one based on reason that looks for the good of all humanity. Nussbaum makes a strong case that liberal education of the whole person to be a good world citizen is the basis of democracy. Reardon suggests that UN documents are an effective source for education on world citizenship and responsibility. UNESCO has one of the largest bibliographies I have found on sources related to a culture of peace. ${ }^{236}$ This view is evident in MTM Phase four, largely comprised of UN source material. The inclusive liberal cosmopolitanism of UN resolutions speak to all of humanity, to 'we, the peoples.'

However, Schick critiques Nussbaum's project of cosmopolitan education, the community of reason, for similar reasons Hutchings, Dauphinée and Shilliam critique mainstream IR, as discussed at

\footnotetext{
${ }^{234}$ Andrew Linklater, "Cosmopolitan Citizenship," Citizenship Studies 2, no. 1 (February 1, 1998): 26, doi:10.1080/13621029808420668.

235 Nussbaum, Cultivating Humanity: A Classical Defense of Reform in Liberal Education, 59.

236 "Appendix 1: UNESCO Publications on a Culture of Peace."
} 
the end of the last chapter. ${ }^{237}$ According to Schick, Nussbaum falls short of her emancipatory aims, as Nussbaum's, "cosmopolitan education project fails to attend to our own implication in oppressive structures." ${ }^{238}$ Existing power relations are not challenged and the 'self/reader' remains positioned as a moral judge that 'consumes' knowledge of the other, without engaging in critical self-reflection. ${ }^{239}$ While the frame of global citizen enables me to examine what PTU is doing through the events discussed below, Brooke repeatedly calls for critical self-reflection in the editorials of MTM, a project that is in tension with the liberal cosmopolitanism of UN texts. There is an element of PTU's vision that is in tension with dominant Liberal cosmopolitan frameworks, the philosophical equivalent of their unconventional structure.

The UN gives "call to actions" to which member states, civil society and individuals respond. The "call to action" the UN publishes in the form of Resolutions and Declarations raises the profile of action on the part of citizens. The Sustainable Development Goals (SDGs), adopted by the UN General Assembly in September 2015, are a prime example of this. The SDGs were formulated through an extensive two year consultation process which to PTU makes the words 'we, the peoples' ring true, although they recognize it is impossible to consult every person or community. ${ }^{240}$ There are structural limitations to the actions a 'citizen of goodwill' can take. Snyder points out that, "the international institutional apparatus is relatively underdeveloped, and the existing institutions face multiple difficulties in promoting cooperation and ensuring enforcement." ${ }^{241}$ The second half of this statement is often given as a reason for a lack of effective action by the UN, the agencies of which often suffer from lack of funds and resources. Snyder, similar to PTU, suggests global social movements are important in addressing this and can put pressure on international institutions in a position to influence government's action. ${ }^{242}$

However, NGOs are often limited by a lack of material power to effect concrete change. In other words, structural limitations affect their capacity to be responsible. These limitations mean that individuals cannot be held accountable for the achievement or lack of achievement of certain international targets. In the current context of nation-states, the most peace-focused NGOs can do to

\footnotetext{
${ }^{237}$ Schick, "Unsettling Pedagogy: Recognition, Vulnerability and the International."

238 Ibid., 30.

239 Ibid.

240 Transforming Our World: The 2030 Agenda for Sustainable Development, RES/70/1, 2015, http://daccessdds-ny.un.org/doc/UNDOC/GEN/N15/291/89/PDF/N1529189.pdf?OpenElement.

${ }^{241}$ Snyder, "Recognition in the Struggle against Global Injustice," 10.

242 Ibid., 175.
} 
respond to global calls to action is to raise the consciousness of themselves and others as to a culture of peace. Theirs is frequently a non-material power. For some, this has resulted in a move to the 'local turn,' while maintaining identification with distant other, the local arena is seen as a more effective arena for action and change. The local is conceptualised, through the formation of a global civil society, as directly linked to the global arena in a way that bypasses the nation-state.

I examine the privileging of the local and global levels of governance in terms of responsibility for developing a culture of peace. PTU works with local governments and civil society on events and projects in their immediate vicinity, while maintaining connections to a global network through MTM and representatives in NY. The relationships formed through both types of activity reinforce PTU's conviction that every individual is responsible for their participation in the development of a culture of peace. One way 'ordinary citizens of goodwill' can do this is through the expansion of an area of mutual agreement through events such as celebrations for the International Day of Peace.

\section{Local days of action}

Local days of action present an opportunity to examine the practical workings of global citizenship as they play out locally. Activists in a global movement for a culture of peace look to local government as a partner in their work for social-change. Adams proposes, "to link civil society to local governments in order to develop culture of peace at the local level."243 Mac Ginty and Richmond draw on the local turn in peacebuilding contexts, and more widely, as a critique of the top-down governmentalism of the 'liberal peace' and structural power. ${ }^{244}$ Although global movements, such as that for a culture of peace, are globally networked, their individual actors still have local agency, as explored by Routledge and Cumbers. ${ }^{245}$ I draw on the examples of the Handspan Sculpture Project and International Day of Peace event 2015. The examples show how PTU's unconventional model gives opportunities and challenges in responding to UN calls to action at different points in the early twenty-first century.

NGOs can come together during Global Days of Action which fit Routledge and Cumbers concept of 'convergence spaces,' another way of thinking about space akin to an area of mutual

\footnotetext{
243 Adams, "Culture or Cultures of Peace?"

244 Mac Ginty and Richmond, "The Local Turn in Peace Building," 764.

245 Paul Routledge and Andrew Cumbers, Global Justice Networks: Geographies of Transnational Solidarity (Manchester University Press, 2009).
} 
agreement. ${ }^{246}$ The International Day of Peace was established in 1981 to coincide with the opening session of the General Assembly, "to devote a specific time to concentrate the United Nations and its member states, and the whole of mankind, to the promoting the ideals of peace and to giving positive evidence of their commitment to peace in all viable ways." 247 Peace Day was moved from the opening session of the UNGA to the fixed date of September $21^{\text {st }}$ in $2001 .^{248}$ The new resolution reiterated the purpose as "devoted to commemorating and strengthening the ideals of peace both within and among all nations and peoples," but removed the above line on giving evidence of a commitment to peace, focusing more broadly on raising public awareness and observation through education. ${ }^{249}$ The new resolution also highlighted the potential for a global ceasefire on this day, as campaigned for by Peace One Day. ${ }^{250}$ This supports Salomon's interpretation of the UN Resolution on a Culture of Peace and related resolutions as aimed at zones of active conflict and warfare. While the goal is a day of global ceasefire, the means to the goal pursued by Peace One Day is awareness, based on the conviction that knowledge of an event leads to change in behaviour. ${ }^{251}$

PTU initiated the Handspan Sculpture project in response to the UN Declaration and Programme of Action on a Culture of Peace, as well as the resolution proclaiming 2001-2010 the International Decade for a Culture of Peace and Non-Violence for the Children of the World. ${ }^{252}$ Brooke writes in MTM that this "call coming from the United Nations member states ... prompted PTU to initiate a project that would depend on the creative and cooperative spirit of the community for its implementation." 253 The Sculpture was dedicated to the children of the world on the International Day of Peace, 21 September 2002. ${ }^{254}$ It stands atop Queens Park, Whanganui NZ, near the cenotaph memorializing the fallen of all Wars, and has since been the focus of other peace day celebrations. ${ }^{255}$ The funding for the Handspan Sculpture was sourced by Gita Brooke through intensive grant

\footnotetext{
246 Ibid.

${ }^{247}$ International Year of Peace and International Day of Peace, A/RES/36/67, 1981, http://www.un.org/en/ga/search/view_doc.asp?symbol=A/RES/36/67.

248 International Day of Peace, A/RES/55/282, 2001, http://www.un.org/en/ga/search/view_doc.asp?symbol=A/RES/55/282.

249 Ibid.

250 "Peace One Day," Peace One Day, accessed February 29, 2016, http://www.peaceoneday.org/. 251 lbid.

252 Gita Brooke, “A Community Response to a UN Appeal," Many to Many, no. 74 (December 2000): 3-4. 253 Ibid.

${ }^{254}$ Brooke, Wanganui Culture of Peace 2002; Brooke, "21 September - The International Day of Peace (Wanganui Culture of Peace Work of Art)"; Gita Brooke, "Dedication of Wanganui Peace Sculpture," Many to Many, no. 82 (December 2002).

255 See title image
} 
applications and fundraising efforts. The Handspan project based in Whanganui was successful in gaining the support and cooperation of the WDC and other community organizations. Was this to do with the focus on one geographic site and the building of a physical, lasting sculpture? Does this mean NGOs should focus on their immediate communities, rather than attempt events in other places, as Adams seems to suggest? Or does it point to the colossal efforts that one individual must make as a driving organizer behind events?

For the International Day of Peace 2015, PTU initiated an event in response to the soon-to-be adopted Sustainable Development Goals (SDGs). PTU was inspired by the zero-sum draft of the SDG declaration, 'Transforming our World by 2030: a new agenda for global action,' which listed nine points summarizing the seventeen goals. ${ }^{256}$ The link between peace and development is expressed in the Preamble of the adopted resolution, "There can be no sustainable development without peace and no peace without sustainable development." ${ }^{257}$ PTU designed an event that would involve community input and individual commitment to actions towards the SDGs. They hoped to move beyond the "paradigm of a talkfest" through an outcome document to be submitted to the UN representative as input to the SDG resolution to be adopted a few days after Peace Day. ${ }^{258}$

As in previous years, PTU partnered with the UNANZ Whanganui Branch to organize the Peace Day event. ${ }^{259}$ The difference was that they proposed hosting it in Wellington at Parliament and so they sought the support of the UNANZ National Council, based in Wellington, to gain the cooperation of the Wellington UNANZ branch. PTU and UNANZ Whanganui tabled a proposal at the UNANZ National Council in February of 2015 for the event and it was accepted. ${ }^{260}$ In July, Gracielli Ghizzi-Hall volunteered to organize the event from the Wellington end. The support of the local Wellington City Council was also secured, as eventually was the support of MP Kennedy Graham to host the event in the (former) Parliament Legislative Chambers. ${ }^{261}$ PTU and UNANZ Whanganui understood that the support of and partnership with civil society, local and national government was attained, reflecting the theme of 2015: 'Partnerships for Peace - Dignity for All. ${ }^{262}$

\footnotetext{
256 Kate Smith, “International Day of Peace 2015," Many to Many, no. 132 (November 2015): 10.

257 Transforming Our World: The 2030 Agenda for Sustainable Development.

258 Kate Smith, Personal Communications, September 2015.

${ }^{259}$ I volunteered to help PTU send out and collate the contributions to the Peace Day event, 2015. I draw on myself as a source of knowledge as I was included in the process of organizing the event.

260 Smith, Personal Communications.

261 Smith, “International Day of Peace 2015," 10.

262 Smith, Personal Communications.
} 
The theme of partnerships raises the issue of the cooperation of NGOs with each other. Adams suggests that by working together for a culture of peace, "the civil society organizations that would normally concentrate on their own particular area, can now take part in a more holistic and mutuallyreinforcing approach involving all the programme areas of a culture of peace." ${ }^{263}$ NGOs rely on their particular area as a result partially of the competition for funding, which makes the NGO landscape a market space of competition, niches and interests. ${ }^{264}$ This splinters the NGO systems, even those aligned with the various organs of the United Nations, into disparate and distinct units. However, a 'holistic and mutually-reinforcing approach' is required to bring about such transformation of society a culture of peace involves. As with Reardon's approach to education, NGO action must also be comprehensive.

However, it would be inaccurate to characterize the NGO landscape as one area of mutual agreement. The splintering of movements in the Left is addressed by Snyder, who underlines that the "struggle against global injustice requires the forging of connections between movements" in what is known as "networked movements." 265 PTU have encountered the parochialism of NGOs throughout their existence. Part of the purpose of PTU's vision for unity is to unite NGOs and social movements (particularly for disarmament in PTU's early days) and make relationships between similar groups stronger so that they could work more effectively together on interconnected issues. Hence the establishment of MTM, which takes "advantages of intersections, points of commonality and opportunities for collaboration," which as Snyder describes, is the point of such networks. ${ }^{266}$

Yet this remains a challenging process when organizing events as there are multiple identities and agendas to balance and unite in cooperation. The Wellington event for the International Day of Peace was not well-supported by the development focused NGOs based in the city. Although they agreed it is good to work together, umbrella organisation the Council for International Development declined to promote the event, stating they already had a consultation process on the SDGs underway with their members and did not want to confuse them with another. ${ }^{267}$ They also questioned why an event on peace was focused on the SDGs, a concern which they raised with the UNANZ President,

\footnotetext{
263 Adams, "Culture or Cultures of Peace?"

264 Ibid.

${ }^{265}$ Snyder, "Recognition in the Struggle against Global Injustice," 184.

266 lbid.

267 The Council for International Development, Personal Communications, September 2015.
} 
despite the fact the agendas of peace and development are closely aligned. Again, the holism of PTU's vision is at odds with other NGOs who have a focused and narrow purpose for their work.

The response from CID and follow-up from the UNANZ National Council speaks to a disconnection in communication and coordination between NGOs even within NZ. It suggests a disconnect between rural and urban centres, even if aligned with their respective councils, a problem that becomes clear in the process of organizing events across centres. PTU is not a member of CID (another case of PTU not fitting the institutional paradigm of NGO) and is so not part of the network of development and humanitarian NGOs in NZ. Communication between the Whanganui branch of UNANZ and the Wellington Branch and National Council is not always effective either, as was the case in the organization of Peace Day. The purpose of an umbrella organization such as CID is to enable this communication and coordination. However, they too are limited in capacity by limited funding and their geographic proximity in Wellington. More sophisticated networking and communication tools are available and in use by larger NGOs such as Red Cross or World Vision. However, geographic proximity still influences the ability of small NGOs with limited resources to achieve their goals and work together.

Indeed, a limitation to action faced by NGOs is securing funding for their activities, the pursuit of which often takes much of their time, and forces NGOs to compete for funding. The competition for limited resources does not encourage cooperation and can greatly reduce the effectiveness of them all. ${ }^{268}$ Adams suggests that the resources needed for projects with city or town officials may be provided by the city or town budget, or provided by funding from other sources more willing to donate to a local government project that an NGO. ${ }^{269}$ This route of funding was pursued for the Peace Day celebrations as the council was a partner. However, very little was provided and most was supplied by UNANZ and PTU.

PTU has worked hard to partner with and include as many individuals and groups in the events and projects they initiate, of which the Whanganui District Council (WDC) is one. In the case of the Handspan Sculpture, PTU discussed the concept with a range of community members to gauge interest before presenting a proposal for a Culture of Peace Sculpture competition to the WDC. PTU needed the Council's permission to build a sculpture on public land, which was granted in April 2000, before

\footnotetext{
268 Adams, "Culture or Cultures of Peace?"

269 lbid.
} 
the competition took place. ${ }^{270}$ Adams suggests partnering with locally elected government "achieves a legitimacy of working for the people as a whole," which would increase "the possibility of broadening the base of involvement to include everyone in the community." ${ }^{271}$ Partnership with the WDC in the form of site permission and major sponsorship undoubtedly increased the legitimacy of the project, but it did not necessarily guarantee widespread community involvement. Brooke, as the initiator of the project, still had to do the hard work of forming relationships with and inviting the participation of the Sarjeant Gallery, the Wanganui School of Design, Iwi, local businesses, schools and community groups. ${ }^{272}$

Community cooperation and participation were essential reasons for the project. As Brooke wrote to the readers of MTM, "OPTU's vision form the beginning has been that we are not merely choosing a work of art, signifying a culture of peace; but that the whole process around completing it would be through community involvement and participation, so that the finished work will become a lasting memento of the community cooperative spirit."273 Indeed, community participation is evidenced most evocatively in the thousands of clay hand casts that line the spiral sculpture. During this project, the flexibility of PTU and hard work needed to cooperate with local government, community members and organizations resulted in a creative and lasting response to a UN call to action. The vision of PTU which puts faith in others, in 'we, the peoples,' to do the necessary work was affirmed.

Community consultation and involvement took a different form for the 2015 Wellington Peace Day event. An 'Invitation to contribute' was sent out to an estimated few hundred New Zealanders in advance of the event. The invitation contained a table with three columns headed with the action point number, thought and ideas, and local actions to achieve action point. ${ }^{274}$ The nine action points were based on the nine summary points of the "zero sum draft" of the sustainable development goals (SDGS), called "Transforming our World by 2030: A New Global Agenda."275 The purpose of the table was to gauge what people knew was already being done in their communities towards meeting the

\footnotetext{
270 Brooke, Wanganui Culture of Peace 2002.

${ }^{271}$ Adams, "Culture or Cultures of Peace?"

272 Brooke, Wanganui Culture of Peace 2002.

273 Brooke, "A Community Response to a UN Appeal."

${ }^{274}$ Meredith Paterson, "International Day of Peace Event Summary Document," United Nations Association of New Zealand, accessed March 28, 2016, http://www.unanz.org.nz/Portals/0/Peace\%20and\%20Security/2015\%2009\%2021\%20International\%20Day\%20 of\%20Peace\%202015\%20Summary\%20Document.pdf; Smith, "International Day of Peace 2015."

275 Transforming Our World: The 2030 Agenda for Sustainable Development.
} 
SDGs, and what more they would be willing to individually commit. The returned contributions would then be synthesized into a document to be presented at the Peace Day Event, as a pledge, by which audience members would add to with commitments to actions in their own communities. The document or pledge would also be presented to the NZ government and representative to the UN as community input to the UN resolution on the SDGs, adopted by the General Assembly on 25 September $2015 .{ }^{276}$ The SDGs were the result of a two year long process of worldwide community consultation, a process which fits with the vision that the UN is 'we, the people.' It was important to the vision of PTU to contribute to this process. However, the logistics of the actual sharing of this information had very real limitations. How the outcome document would be formulated was unclear as was to whom it would be submitted and the actual likelihood of its inclusion in the UN outcome document.

UNANZ and OPTU received fifteen responses from around Aotearoa NZ. While this is a small proportion of the invitations sent, the replies came from a range of sources. Contributors included six individuals, two UN Associations, two embassies, a business network, a university faculty, a university club and two regional organisations. ${ }^{277}$ While we asked for local actions, many contributors gave global actions too which shows that the interconnectedness of local and global contexts is already present in civil society consciousness. PTU has attempted similar consultation through contributions of thoughts and actions before, as seen in MTM. They have also organized events in Wellington before, in conjunction with UNANZ, when Dame Laurie Salas was National President that have been successful. ${ }^{278}$ PTU and UNANZ therefore had precedents to suggest the 2015 event was achievable. But the 2015 event encountered more challenges than Brooke had remembered in previous organizational efforts. ${ }^{279}$ The vision for the event could not be maintained due to a lack of resources, support and cooperation. What took place was a conventional event with keynote speaker, panel discussion and question and answer time. In these terms it was a success, with an estimated 200 attendees from Whanganui and Wellington. ${ }^{280}$ That a pledge was not formulated and submitted to a NZ government representative changed the purpose of the event from one focused on community consultation, to another panel discussion in the capital city.

\footnotetext{
276 Ibid.

277 Paterson, “International Day of Peace Event Summary Document," 4.

278 Brooke, Interview 3.

279 lbid.

${ }^{280}$ Smith, “International Day of Peace 2015," 10.
} 
Yet the proposed way of moving the event beyond the 'paradigm of a talkfest' through an outcome document of individual commitment to go to the UN simply moves it to a written talkfest in a larger forum. An outcome document and the resolution of the SDGs are not the practical outcomes in the redistribution of resources and power desired by social movements. And yet, texts as communication can be considered a form of action. The challenges faced by PTU during the organizing process of Peace Day 2015 speak to the same challenges faced by the UN General Assembly. Again, complex issues of language and power are at stake. The binary of talk/action is unhelpful when thinking of the political configurations of power. How then can individuals respond, and take responsibility for, calls to action at a global scale? The information sharing role of MTM is one answer, as is the Handspan Sculpture, and the International Day of Peace Event. All have an educational element that contributes to worldview transformation towards a culture of peace.

On top of these, as an attempt to answer to this question, I turn back to my previous point on the vision of PTU as contradicting the moral rationalism of liberal cosmopolitanism. The binary of thought/action in the context of NGOs privileges 'useful' knowledge, or instrumental reason, as leading to action that solves problems. However, the danger is that NGOs will not see how they are implicated in structures that oppress, as has been widely critiqued in the context of good intentions causing harm. PTU's unconventional model has enabled them to be more critically self-reflective when working for peace, in the space created by the spiritual underpinnings of their vision. MTM, the deterritorialized publication situated in a shared language, provides a space for critical self-reflection on the actions of NGOs and UN agencies, framed by spiritual thoughtfulness. The binary of thought/action collapses in these spaces as alternative ways of knowing and being as a network, connected across pages and oceans, develops. Theses spaces or places are convergence spaces or areas of mutual agreement that aim for unity. Individuals, who have critically reflected on their place in the world, can connect with others who have done the same and continue the work of cultural change together.

The International Day of Peace Event 2015 made space for the development of a sense of global citizenship. In was held in conjunction with the High Level Forum organized by Spellings, which similarly raised the SDGs as important, fostering a connection between Wellington and New York. The panellists at the Wellington Event spoke on the 'Invincible Power of the Community Spirit' and the oneness of humanity. ${ }^{281}$ In reference to the SDGs, care for distant others, but also the need to commit to action in our local communities was highlighted. Nussbaum's conception of world citizenship thus

\footnotetext{
${ }^{281}$ Paterson, “International Day of Peace Event Summary Document," 7.
} 
merged with the local turn in peacebuilding. While the theme was undeniably cosmopolitan, as was the conception of a global citizen in meeting the challenges of the SDGs, PTU also introduced a space for critical self-reflection, more similar to the education advocated by Schick although outside a formal educational setting. ${ }^{282}$ Perhaps this was more so for the organisers from PTU and UNANZ Whanganui end, including myself, than for the guests at the event. The process of organising the event shook the certainties in the ordinary citizen of goodwill, especially those part of NGOs, to commit to the highest ideals of peace work expressed in the seven points of PTU's vision. PTU's original vision for the event could not be realized. What was achieved was largely due to the hard work of Ghizzi-Hall, working on behalf of UNANZ National Council, who told Brooke and Smith that she was, "the hands, they are the heart." 283 Ghizzi-Hall was based in Wellington, so able to adjust PTU/UNANZ Whanganui's vision for the event in a way that connected the two places. Again, much of this work was communication between the various partners and agendas to build relationships for peace. The parts of PTU/UNANZ Whanganui's vision that were not well thought out, such as the contribution to the resolution on the SDGs, were parts that they expected 'ordinary citizens of goodwill' at UNANZ Wellington to put into motion.

\footnotetext{
${ }^{282}$ Schick, "Unsettling Pedagogy: Recognition, Vulnerability and the International," 33.

${ }^{283}$ Smith, Personal Communications.
} 


\section{Chapter 5: Conclusion}

"Most people working for a peaceful, healthy and non-violent world are realizing sometimes with considerable frustration - that such a goal cannot be achieved by force, or by inducing a change of behaviour through fear, bribery or totalitarian means. Peace cannot invade a country, a culture, or a person. Through our many years of travel and work within the world disarmament movement in the 1980s early 90s Anthony and I saw the results of such attempts to quick conversion and recruiting of people for disarmament. This often led to rather intolerant, judgmental and confrontational approaches to peace. Peace cannot be built on fear or indoctrination. It must be built on reliable and balanced information, resulting in deeper understanding, leading to carefully considered action. It is a process of change and transformation from the inside out - for all of us. ${ }^{284}$

\section{Extending the brief of narrative politics in IR}

Narrative politics presents a challenge to IR to listen to the voices of 'ordinary' people more often. Their stories are rich and full of lived experience that challenges the abstract theorising of moral judges. I have made space in this thesis for the voices of Gita Brooke, her co-workers Kate Smith, Iris Spellings and Steve Nation, and some of the many readers, known and unknown, of MTM. Narrative politics challenges IR to pay attention to the connections between people, even if they live in geographically dispersed places. These connections may be felt in a spiritual sense, drawing on complex human faculties for emotion and feeling, urging IR to pay attention to spirituality and non-rational ways of knowing in the discipline. Narrative politics provides a way of writing that shows the embeddedness of the researcher in the social world and highlights the importance of relationships in the cultivation of knowledge. I sum up by relating PTU to three core aspects of narrative politics: vulnerability, relational ethics and authorial voice. These aspects intersect and relate to the three themes of the chapters: education, transformation and responsibility.

\footnotetext{
${ }^{284}$ Brooke, "Philosophical Reflections: The UN and a New World Order."
} 
An area of mutual agreement requires vulnerability in writing and person. Narrative politics has urged the questioning of adversarial and defensive modes of argument and debate as inhibiting creativity. It allows the researcher to step out of the cocoon of moral rationality that is certain and invulnerable to attack in order to reengage with the social world. This opens up the possibility of injury, requiring vulnerability. PTU describe another space in which to move: an area of mutual agreement. This can be a difficult place to build, as it require openness, vulnerability and a sharing of commonalities. These commonalities can be as simple as two parents sharing concern for the future of their children. The pages of MTM are a place for peace workers and educators to share and network activities and vision for peace, as Abileah, Kimball and Huber do. It represents an area of mutual agreement, in which the readers have a shared worldview for peace, a unitive-worldview, and while there are differences, there is little disagreement. This area does not necessarily extend to other print publications, as seen in Gita and Theo's letters to the editor. One can be vulnerable in print, however, the face to face provides for a powerful encounter. The various events PTU have been involved in over the years, including the Handspan Sculpture and International Day of Peace celebrations, have provided space for the creation of an area of mutual agreement as convergence space. This space in educative and elicits critical self-reflection, thus raising the potential for worldview transformation, although this is a difficult process.

A new form of relational ethics can emerge when academics adopt a more vulnerable posture to attack and defence in order to cultivate knowledge in a more complex way. Dauphinée has made inroads on how to do this in her work, as has Shilliam. Recognizing shared vulnerabilities can equalize the power imbalance between researcher and research subject, knower and known. PTU have moved through the world and local community in a way that puts relationships first, in line with the convictions of the seven points of their vision. It was my relationship with Gita Brooke that sparked this project. I have learnt first-hand some of the responsibilities narrative politics provokes in the process of oral history interviews and writing various iterations. Narrative politics, in a similar way to autoethnography, allowed me to draw on my personal experience in the process of organizing the 2015 Peace Day celebrations, including collating the contributions and summary document. Dauphinée speaks to the trust, or faith she calls it, we have or lack in the research process. Brooke has trusted me to represent the vision of PTU in an IR setting and I have trusted her as a collaborator.

However, there is more that this thesis could have done. In terms of authorial voice, I have used the personal ' $I$ ' and spoken as present in the archive of Rumah Brooke or in conversation with 
Gita or as a student in Wellington. I have included elements of Gita's story and the narrative of PTU, but I have not completely dived into narrative as a research methodology and written the whole thesis in purely narrative form (also in recognition of the requirements of the university). It has been difficult to balance the university requirements of a Master's thesis, as well as my responsibilities to PTU, in a way that does justice to both. Through the process I have better recognized my own limitations as skills to be developed, including speaking with my own voice in an academic setting. Being upfront with my connection to the project and my situation in the world of PTU has been a starting point to do this.

I have connected the concerns of narrative politics with how academics cultivate knowledge to question the binary of thought and action in the NGO space. I have shown how PTU's unconventional model provides opportunities and challenges to working for peace within and between hierarchal institutions, such as the UN. Through this, one can see that communication is a form of action and networks such as MTM vital work for peace. The concept of global citizenship provides a frame to examine how PTU views the responsibilities of 'we, the peoples,' or the 'ordinary citizen of goodwill.' However, the liberal cosmopolitanism of the UN stands at tension with the thread of PTU's vision that calls for critical self-reflection to see how we are all implicated in structures of violence and have the potential to act in a violent way. The quote that begins this chapter sums up PTU's vision, based on their experience, in a succinct way. Brooke says, "Peace cannot be built on fear or indoctrination. It must be built on reliable and balanced information, resulting in deeper understanding, leading to carefully considered action." ${ }^{285}$ This calls for a comprehensive process of peace education, which does not end when a student leaves the classroom, full of critical self-reflective thought leading to worldview or consciousness change towards a culture of peace.

\section{Future directions for research}

Such an extensive archive offers many possibilities for research directions. Using 'Towards Peace Through Unity' as the interpretive thematic key to the corpus of MTM provided direction for this thesis but much fascinating evidence was still left out. The Brooke's contribution to peace work, in tandem with the digitization underway, points to the need for a fuller life history of Anthony and Gita Brooke and their work as PTU. Oral history interviews and the archive at Rumah Brooke would provide ample

285 Ibid. 
evidence for biographical work. An ethnographic approach might also seek to visit Sarawak and England in which there are sites connected to the Brooke family, as well as Bornholm, Denmark or Tamil Nadu, India, where Gita spent her early life. Further, every object in Rumah Brooke has a story. From a museum and cultural studies approach, one could tell the story of Anthony and Gita Brooke through the objects, and glean fascinating insights into the lives of everyday people through a time of 'unprecedented change and transformation' as they travelled the world.

A future research project could do a more in-depth study the network of MTM from a print culture framework, focusing on the production, distribution and reception of the newsletter. The addresses of early contributors were noted on the contents page and countries of distribution were also noted early on, giving some indication of the spread of distribution. One could survey the existing readers on the email list about their reception of the newsletter over the years to find out more about the network of peace people.

While this thesis drew on a range of literature, connecting many conversations, it could have been focused more on the literature concerning network activism and globalisation. The number of UN accredited NGOs has hugely increased since PTU began their work. It would be fascinating and valuable work to examine the intricacies of this network horizontally and the hierarchical interactions with the sprawling bureaucracy of the UN.

Finally, there is a Utopian element to PTU's vision that I did not have room to elaborate in this thesis. Future research could also consider how the hope for a better future plays out in deterritorialized networks such as MTM or a culture of peace. Is a culture of peace a Utopian in the Marxist sense of redistribution of resources in a just world? The narrative of the editorials speaks to new world structures emerging as the old collapse. Or could we read PTU in light of the practical utopia literature? Wahat al-Salaam/Neve Shalom, a contributor to MTM, can be considered a practical utopia or intentional community. There is a rich history of intentional communities in Aotearoa NZ, yet PTU did not join one or start their own, although they have a very community orientated vision for their house. Philosophically and practically, this would be an interesting line of research.

Evidently, the vastness of the Brooke archive contains many directions for fascinating and worthwhile research. The process this entails is well captured, in a manner akin to narrative politics, by Historian Arlette Farge, in The Allure of the Archive. She says, "The allure of the archives entails a roaming voyage through the words of others and a search for a language that can rescue their 
relevance." 286 The language of narrative politics as a challenge to mainstream ways of knowing and judging in IR was a powerful way to explore the relevance of PTU. Narrative politics is an ongoing project and process of transformation, as is the work of peace people such as Gita and Anthony Brooke.

${ }^{286}$ Arlette Farge, The Allure of the Archives (Yale University Press, 2013), 23. 


\section{Bibliography}

Abileah, Joseph. "The Bridge to Peace." Many to Many, no. 2 (December 1982): 6.

- - - Edited by Gita Brooke. Many to Many, no. 11 (March 1985): 8.

"About the Journal." Journal of Narrative Politics, 2016. http://journalofnarrativepolitics.com/.

“About World Goodwill - World Goodwill (Lucis Trust)." Accessed February 10, 2016.

https://www.lucistrust.org/world_goodwill/about_wg.

Adams, David. "Culture or Cultures of Peace?" Culture of Peace. Accessed January 11, 2016.

http://culture-of-peace.info/vita/2010/Culture_or_Cultures_of_Peace.html.

“Alice Bailey Books | Books \& Publications Store (Lucis Trust)." Accessed March 30, 2016.

https://www.lucistrust.org/store/category/alice_bailey_books_p.

“Appendix 1: UNESCO Publications on a Culture of Peace." Accessed March 30, 2016.

http://www.culture-of-peace.info/annexes/resA-53-370/pages42-49.html.

Baxter, Archibald. We Will Not Cease. 2nd ed. Christchurch: Caxton Press, 1969.

Beattie, Amanda Russell, and Kate Schick. The Vulnerable Subject: Beyond Rationalism in International Relations. Palgrave Macmillan, 2012.

Boulding, Elise. Cultures of Peace: The Hidden Side of History. Syracuse University Press, 2000.

Brigg, Morgan, and Roland Bleiker. "Autoethnographic International Relations: Exploring the Self as a Source of Knowledge." Review of International Studies 36, no. 3 (July 2010): 779-98. doi:http://dx.doi.org.helicon.vuw.ac.nz/10.1017/S0260210510000689.

Brooke, Anthony. “Anthony's Story - After Sarawak, 1951-1970." Operation Peace Through Unity. Accessed January 12, 2016. http://www.peacethroughunity.info/backgroundanthonystory7.html.

-- - "Anthony's Story Continued, 1970-Present." Operation Peace Through Unity. Accessed January 12, 2016. http://www.peacethroughunity.info/backgroundanthonystory8.html\#here.

- - . "Anthony's Story - Continued, Visiting Sarawak 1983 \& 1991." Operation Peace Through Unity. Accessed January 12, 2016. http://www.peacethroughunity.info/backgroundanthonystory9.html\#here.

Brooke, Gita. "21 September - The International Day of Peace (Wanganui Culture of Peace Work of Art)." Many to Many, no. 81 (September 2002).

- - . "A Community Response to a UN Appeal." Many to Many, no. 74 (December 2000): 3-4. 
- - . , ed. "Become a Culture of Peace Reporter." Many to Many, no. 124 (June 2013).

- - "Creating a Culture of Peace: Banner of Peace - Manifesto 2000." Many to Many, no. 83 (March 2003): 4.

--_. "Dedication of Wanganui Peace Sculpture." Many to Many, no. 82 (December 2002).

- - "Editorial - Newness." Many to Many, no. 111 (March 2010): 2.

- - - , ed. "Education for Peace." Many to Many, no. 124 (June 2013).

-- - Interview 1, August 24, 2015.

- - Interview 2, August 25, 2015.

- - Interview 3, November 13, 2015.

- - . , ed. "Neve Shalom/Wahat Al-Salam." Many to Many, no. 25 (September 1988): 5.

- - . , ed. "Neve Shalom/Wahat Al-Salam - a Community of Peace Working for Arab-Jewish Coexistence and Cooperation - Struggles to Assure Its Future." Many to Many, no. 63 (March 1998): 10-11.

- - - "Philosophical Reflections: The UN and a New World Order." presented at the The United Nations Association of New Zealand Seminar on Global Governance and UN Reform, Wellington, New Zealand, June 25, 1993.

--_. "The Burning Issue." Wanganui Chronicle. March 14, 1991, sec. Letters.

- - . "The Gulf War." Wanganui Chronicle. February 15, 1991, sec. Letters.

- - . "Towards Peace Through Unity." Peace Through Unity, 1975. http://www.peacethroughunity.info/archives_1975pam.html.

--_. "Unity Worth Working for." Wanganui Chronicle. February 27, 1991, sec. Letters.

- - - , ed. Wanganui Culture of Peace 2002. Wanganui: Peace Through Unity, 2002.

- - , ed. Many to Many, no. 2 (December 1982): 1-13.

"Brooke Heritage Trust." Brooke Heritage Trust. Accessed February 11, 2016. http://www.brooketrust.org/.

"Building a Culture of Peace and the Evolution of Consciousness." Many to Many, no. 89 (September 2004): 3-4.

Charter of the United Nations, 1945. http://www.un.org/en/sections/uncharter/preamble/index.html.

Clements, Kevin. "New Wars - Olds Wars: Thinking Creatively about the Prevention and Transformation of Violent Conflict in the Twenty-First Century." In Activating Human Rights 
and Peace: Theories, Practices and Contexts, edited by GOH Bee Chen, Baden Offord, and Rob Garbutt. England: Ashgate Publishing, Ltd., 2012.

Cohn, Carol. "Sex and Death in the Rational World of Defense Intellectuals." Signs 12, no. 4 (July 1, 1987): 687-718.

Danesh, H. B. "Towards an Integrative Theory of Peace Education." Journal of Peace Education 3, no. 1 (March 1, 2006): 55-78. doi:10.1080/17400200500532151.

Dauphinee, Elizabeth. "The Ethics of Autoethnography." Review of International Studies 36, no. 3 (July 2010): 799-818. doi:http://dx.doi.org.helicon.vuw.ac.nz/10.1017/\$0260210510000690.

Dauphinée, Elizabeth. The Ethics of Researching War: Looking for Bosnia. 1 edition. Manchester; New York; New York: Manchester University Press, 2007.

-- - The Politics of Exile. New York, NY: Routledge, 2013.

Doty, Roxanne Lynn. "Maladies of Our Souls: Identity and Voice in the Writing of Academic International Relations." Cambridge Review of International Affairs 17, no. 2 (July 1, 2004): 377-92. doi:10.1080/0955757042000245951.

Farge, Arlette. The Allure of the Archives. Yale University Press, 2013.

Freire, Paulo. Pedagogy of the Oppressed. England: Penguin, 1996.

Glassie, Henry. "Material Culture." In Material Culture, 41. Bloomington \& Indianapolis: Indiana University Press, 1991.

Hamilton, Ian. Till Human Voices Wake Us. Auckland University Press, 1953.

Huber, Helen. "Letter XIII." Many to Many, no. 26 (December 1988): 13.

Huber, Helen, and David Kimball. "Building a Culture of Peace and the Evolution of Consciousness Responses." Many to Many, no. 90 (December 2004): 13-14.

Hutchings, Kimberly. "A Place of Greater Safety? Securing Judgement in International Ethics." In The Vulnerable Subject, edited by Kate Schick and Amanda Russell Beattie, 25-42. United Kingdom: Palgrave Macmillan, 2013.

International Day of Peace. A/RES/55/282, 2001.

http://www.un.org/en/ga/search/view_doc.asp?symbol=A/RES/55/282.

International Year of Peace and International Day of Peace. A/RES/36/67, 1981.

http://www.un.org/en/ga/search/view_doc.asp?symbol=A/RES/36/67.

“IPS - Inter Press Service News Agency » Federico Mayor Zaragoza.” Accessed March 21, 2016.

http://www.ips.org/institutional/our-global-structure/biographies/federico-mayor-zaragoza/. Israeli Pacifist: The Life of Joseph Abileah. Diane Pub Co, 1990. 
Jackson, Richard. Confessions of a Terrorist. London: Zed Books Ltd, 2014.

- - . "Terrorism, Taboo, and Discursive Resistance: The Agonistic Potential of the Terrorism Novel." International Studies Review 17, no. 3 (September 1, 2015): 396-413. doi:10.1111/misr.12227.

Kaldor, Mary. "Introduction." In The Imaginary War: Understanding the East-West Conflict, 3-8. Oxford: Oxford, 1990.

Khan, Sorayya. "The Silence and Forgetting That Wrote NOOR." Journal of Narrative Politics 1, no. 2 (March 2015): 121-32.

Leadbeater, Maire. Peace, Power, Politics: How New Zealand Became Nuclear Free. Dunedin: Otago University Press, 2013.

Linklater, Andrew. “Cosmopolitan Citizenship.” Citizenship Studies 2, no. 1 (February 1, 1998): 23-41. doi:10.1080/13621029808420668.

Locke, Elsie. Peace People: A History of Peace Activities in New Zealand. Christchurch: Hazard Press, 1992.

Lowenheim, Oded. "The 'I' in IR: An Autoethnographic Account." Review of International Studies 36, no. 4 (October 2010): 1023-45. doi:http://dx.doi.org.helicon.vuw.ac.nz/10.1017/S0260210510000562.

Mac Ginty, Roger, and Oliver P Richmond. "The Local Turn in Peace Building: A Critical Agenda for Peace." Third World Quarterly 34, no. 5 (June 1, 2013): 763-83. doi:10.1080/01436597.2013.800750.

“Many to Many Current." Operation Peace Through Unity. Accessed March 21, 2016. http://www.peacethroughunity.info/manytomany_current.html.

Mayor Zaragoza, Federico. "The Crime of Silence." Www.fund-Culturadepaz.org. Accessed March 22, 2016. The_Crime_of_Silence_FM.pdf.

Muppidi, Himadeep. “On The Politics of Exile.” Security Dialogue 44, no. 4 (August 1, 2013): 299-313. doi:10.1177/0967010613493457.

Nation, Steve. Personal Communications, November 24, 2015.

"Newsletter." World Goodwill, 1995.

Nussbaum, Martha C. Cultivating Humanity: A Classical Defense of Reform in Liberal Education. United States of America: Harvard University Press, 1997.

"Operation Peace through Unity." Glastonbury Archive, Isle of Avalon. Accessed March 22, 2016. http://www.isleofavalon.co.uk/GlastonburyArchive/manymany/issue-62/mm-62h.html. 
Page, James S. "The International Year for the Culture of Peace Was It Worthwhile?" International Journal of Cultural Studies 4, no. 3 (September 1, 2001): 351. doi:10.1177/136787790100400305.

Paterson, Meredith. "International Day of Peace Event Summary Document." United Nations Association of New Zealand. Accessed March 28, 2016. http://www.unanz.org.nz/Portals/0/Peace\%20and\%20Security/2015\%2009\%2021\%20Intern ational\%20Day\%20of\%20Peace\%202015\%20Summary\%20Document.pdf.

“Peace One Day." Peace One Day. Accessed February 29, 2016. http://www.peaceoneday.org/. Pogacnik, Marko. Many to Many, no. 4 (May 1983): 5.

Reardon, Betty A. Comprehensive Peace Education: Educating for Global Responsibility. New York, NY: Teachers College Press, Columbia University, 1988.

-- Many to Many, no. 26 (December 1988): 5.

Richmond, Oliver P. “Patterns of Peace.” Global Society 20, no. 4 (October 1, 2006): 367-94. doi:10.1080/13600820600929705.

Rivera, Joseph de. "Introduction." In Handbook on Building Cultures of Peace, edited by Joseph de Rivera, 1-8. Peace Psychology Book Series. Springer New York, 2009. http://link.springer.com/chapter/10.1007/978-0-387-09575-2_1.

Routledge, Paul, and Andrew Cumbers. Global Justice Networks: Geographies of Transnational Solidarity. Manchester University Press, 2009.

Salomon, Gavriel. Peace Education: Its Nature, Nurture and the Challenges It Faces. Springer New York, 2009. http://link.springer.com/chapter/10.1007/978-0-387-09575-2_8.

Schick, Kate. "Unsettling Pedagogy: Recognition, Vulnerability and the International." In Recognition and Global Politics: Critical Encounters Between State and World, edited by Patrick Hayden and Kate Schick, 25-44. Manchester: Manchester University Press, 2016.

Scott, Dick. Ask That Mountain: The Story of Parihaka. Auckland: Reed Books, 1975.

Shilliam, Robbie. The Black Pacific: Anti-Colonial Struggles and Oceanic Connections. London: Bloomsbury, 2015.

Smith, Kate. “International Day of Peace 2015." Many to Many, no. 132 (November 2015): 9-11.

--- Personal Communications, September 2015.

Snyder, Greta Fowler. "Recognition in the Struggle against Global Injustice." In Recognition and Global Politics: Critical Encounters Between State and World, edited by Patrick Hayden and Kate Schick, 175-94. Manchester: Manchester University Press, 2016. 
Spellings, Iris. Personal Communications, November 17, 2015.

- - "We the Peoples: The Culture of Peace \& Fulfilling the Mission of the United Nations." Edited by Gita Brooke. Many to Many, no. 124 (June 2013).

"Support of the United Nations (Lucis Trust)." Accessed February 10, 2016. https://www.lucistrust.org/about_us/support_un.

The Council for International Development. Personal Communications, September 2015.

"The Homepage of Gita and Anthony Brooke." Angel Fire. Accessed March 22, 2016. http://www.angelfire.com/journal/brooke2000/.

Theo. "Interesting Points." Wanganui Chronicle. March 5, 1991, sec. Letters.

- - . "Peace and War." Wanganui Chronicle. February 22, 1991, sec. Letters.

“The Spiritual Caucus at the United Nations." Accessed March 21, 2016.

http://www.spiritualcaucusun.org/.

Transforming Our World: The 2030 Agenda for Sustainable Development. RES/70/1, 2015. http://daccess-ddsny.un.org/doc/UNDOC/GEN/N15/291/89/PDF/N1529189.pdf?OpenElement.

"United Nations Civil Society Participation - Department of Public Information." Accessed March 21, 2016. http://esango.un.org/civilsociety/displayDPISearch.do?method=redefine.

United Nations Declaration and Programme of Action on a Culture of Peace. A/RES/53/243, 1999. undocuments.net/a53r243a.htm.

Urlich, John. Journey Towards World Peace: A History of the New Zealand Peace Council. Wellington: Lake Ohia Publications, 1998.

Weber, Cynthia. International Relations Theory: A Critical Introduction. 3rd ed. New York, N.Y., United States: Routledge, 2010.

Wright, Kenyon. Coventry - Cathedral of Peace: Healing the Wounds of History in International Reconciliation. AuthorHouse, 2012. 


\section{Appendix}

Appendix 1: Example from Phase one, Many to Many, Issue 2, December 1982

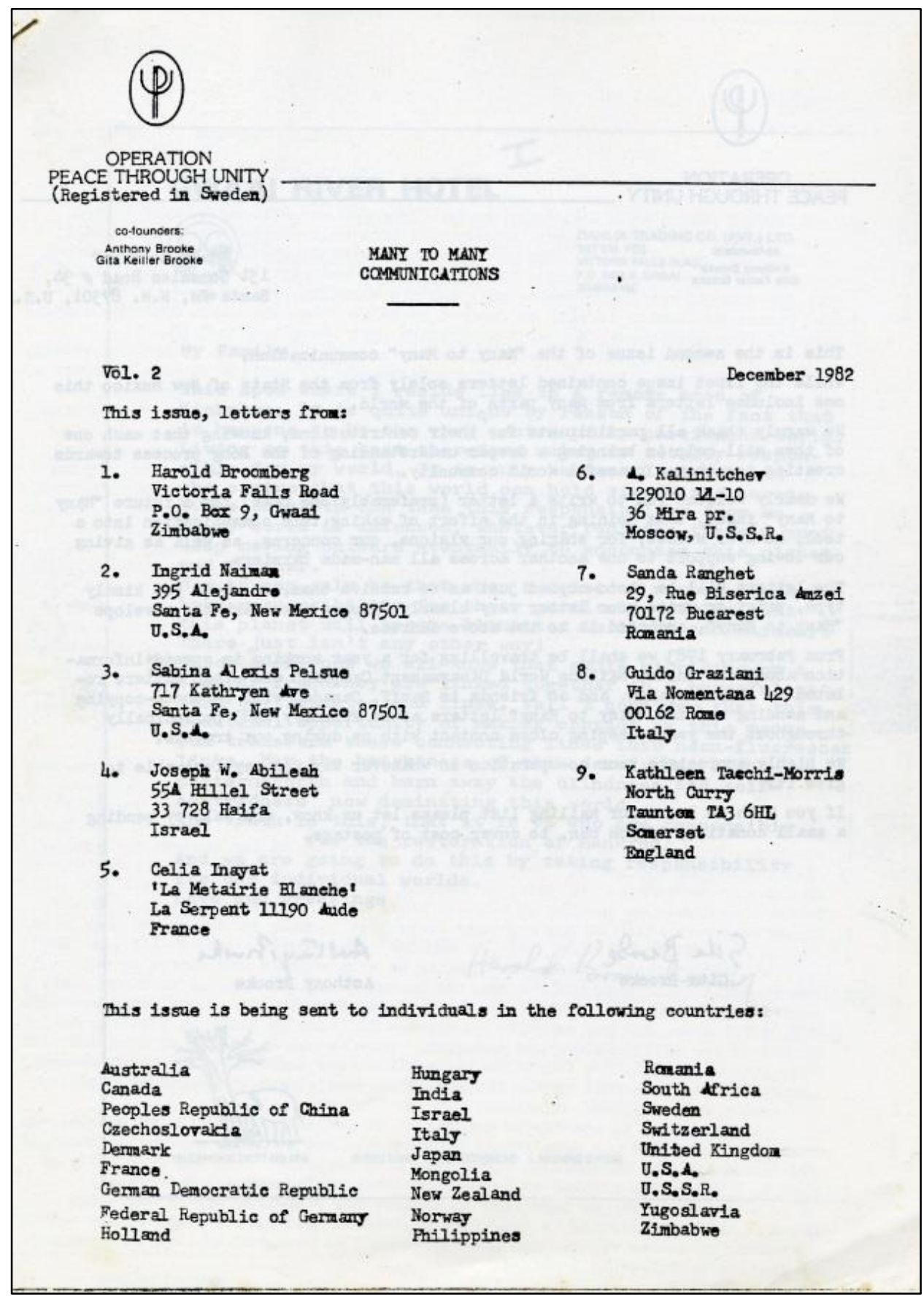




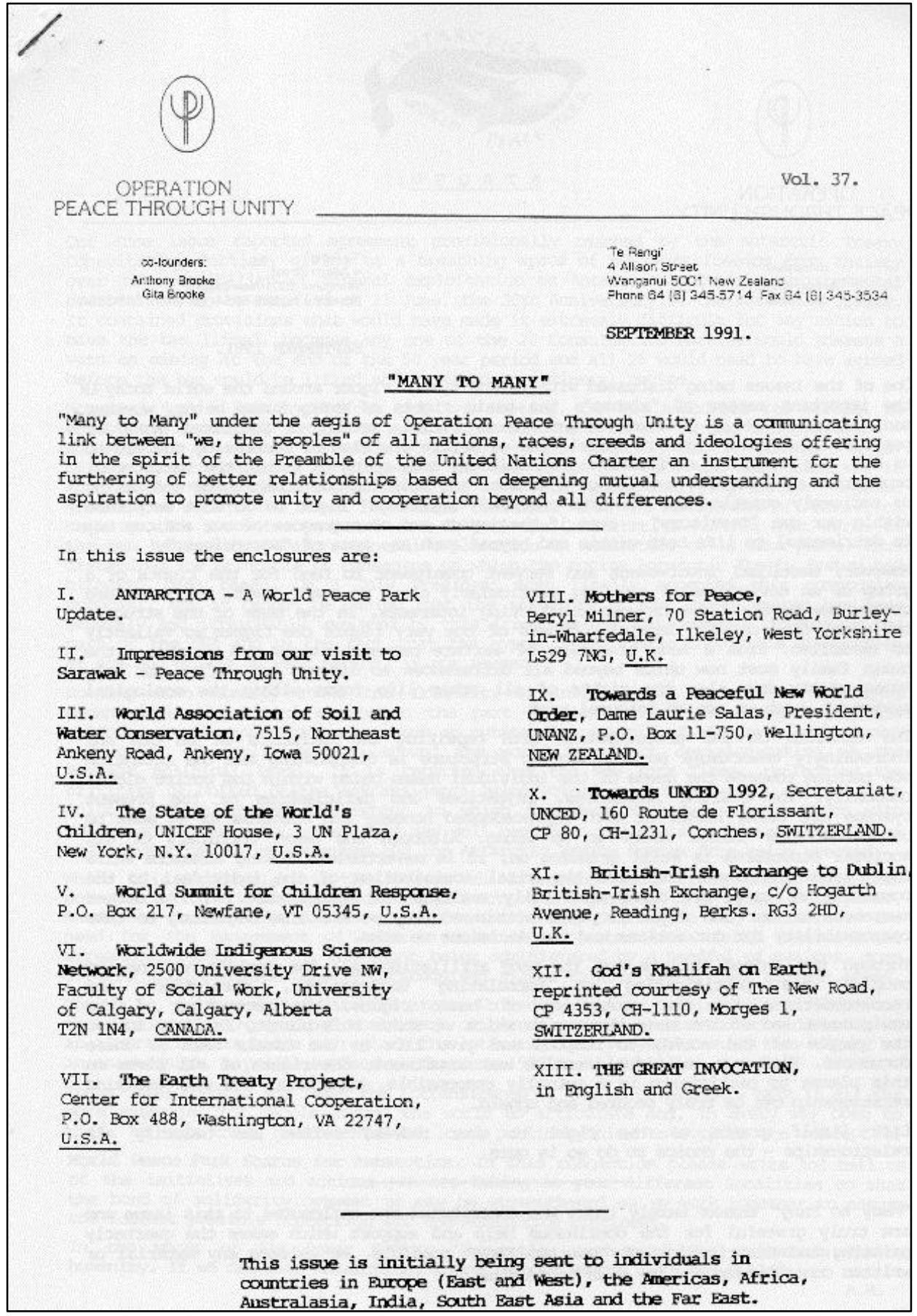




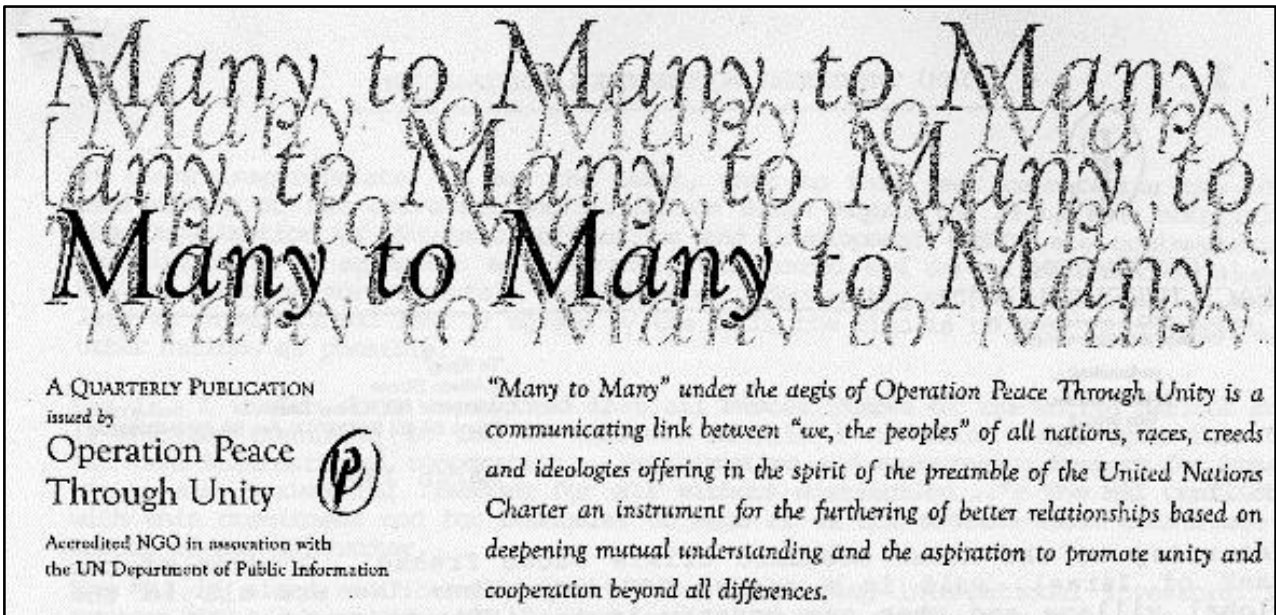

Issue Number 63

March 1998

E N CLOSURES

I. THE MULTIIATFRAL AGREFMEQT ON INVESTMENI (NAI).

II. OPTU SOON ON THE NET.

III. NEW ZEALAND FORUM FOR UN RFAEWRI

IV. INIO THE GREPNHOUSE CENIURY, Report from Kyoto, PIANET 21

1 woturn Walk, London wcll OJJ, U.K.

V. ARTSTOTLE UNIVERSITY OF THESSALONIKI UNESCO CHAIR ON Education for Human Rights and Peace: Prof. Dimitra Papadopoulou, Aristotle University of Thessaloniki, Dept. of Psychology, Thessaloniki 54006, GREECE

VI. BEYONU REFCRM: The United Nations in a New Era, The Stanley Foundation, 216 Sycamore St., Suite 500, Nuscatine, IA 52761, U.S.A.
VII. NEVE SHALOM/WAHAT AL-SALAM, Struggles to Assure its Future, Doar Na Shimshon 99761, ISRAEL.

VIII. YOU AND THE UN. Norld Civil society Forum Group, 308 cricklewood Lane, Lonaion $\mathrm{N} / 2 \mathrm{2PX}, \mathrm{U} . \mathrm{K}$.

IX. CHILDREN'S CHOIR FESTIVAL FOR FRTENDSHIP. Felicity Iaurence, Dorfstrasse 27, Durchhausen, GERMANY 78591.

X. WATER AND LIFE. Birthe Zimnermann, Baltic Sea Project Newsletter, Sondre Sandevej 18 , DK-6400 Sonderborg, DENMARK.

XI. THE GREAT INVOCATION, English and Icelandic. 


\section{Many to Many}

A Quarterly Publication

Issued by

Operation Peace

Through Unity

Accredited NGO in

association with the UN

Department of Public

Information
"Many to Many" under the aegis of Operation Peace Through Unity is a communicating link between "we, the peoples" of all nations, races, creeds and ideologies offering in the spirit of the preamble of the United Nations Charter an instrument for the furthering of better relationships based on deepening mutual understanding and the aspiration to promote unity and cooperation beyond all differences.

I. EDITORIAL - Climate

II. PROPOSED ESTABLISHMENT OF A CENTRE FOR PEACE AND CONFLICT STUDIES IN AOTEAROA NEW ZEALAND

III. INTERNATIONAL PEOPLE'S INITIATIVE FOR DEPARTMENTS OF PEACE

IV. 'THE CREATIVE IMPERATIVE'

V. 'NEW MINDSET'

VI. PRINCIPLES FOR RESPONSIBLE INVESTMENT (PRI)

VII. SWISS BUSINESS SCHOOL

VIII. CONVENTION ON DISARMAMENT - Threats to Peace and Disarmament: the Way Forward

IX. WATER FOR LIFE

X. USING THE GREAT INVOCATION ON JUNE 11

XI. THE GREAT INVOCATION

Anthony Brooke \& Gita. Rrooke, co-founders Te Rangi, 4 Allison Street, Wanganui 5001, New Zealand PHONE/FAX: 64-6-345-5714 Website: www.peacethroughunity.info or www.igleofavalon co.ukimanytomanv. htm] of www angelfire.com/jounsal brooke 2000 Email optubrookiana/artra.co.nz

ORDER THE EMAIL EDITION OF MANY TO MANY BY SENDING AN EMAII TO: optusteve@earthlinknet with 'Many to Many subscribe' in the subject line. 


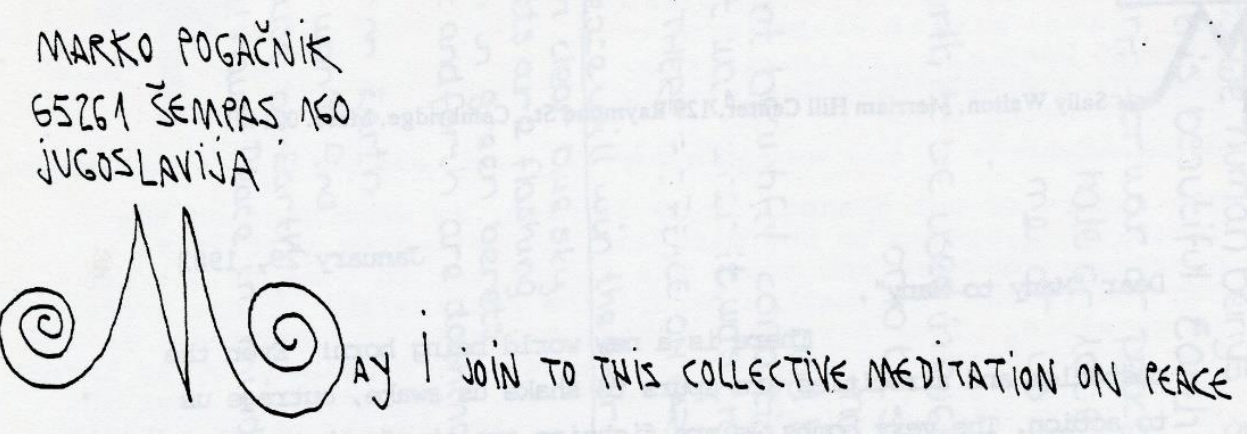

THROUGH UNITY TAAT IS DEVELOPINE HERE. FOR ME IT IS NOT JUST A COLLETTIMI OF OUR COMMON DREAMS SUT A POWERFULL INYOCATION IN WHICH OUR PERSONAR ENERGIES ARE STRENGTHENED BY THE EARTHCY STREAMS OF ENERGY EMANTTING FROM TAE PLACES FROM WHICH OUR LETTERS ANE COMMING AND FRUM THOSE TO WHICH THEY ARE GOING.

WritEING thIS LETTER MY FEET ARE TOUCHING TNIS HOLY EARTH, WNILL READING IT, OTNERS WILL BE TOUCHING OTHER SPOTS ALL OVER THE PLANET. WNIE OUR FEE NGS AND TROUGNTS WILL BE PONDERING VPON PEACE AND UNITY, Wi't SHALL IN FACT BECOME PKACEFUCL, TAUS UNITING OUR POINTS OF TNE GARTH: ALL IN ALL: A DELIKATE BUT CRETTIVE MOVEMENT LIKE THIS: MAY IT BE SO.

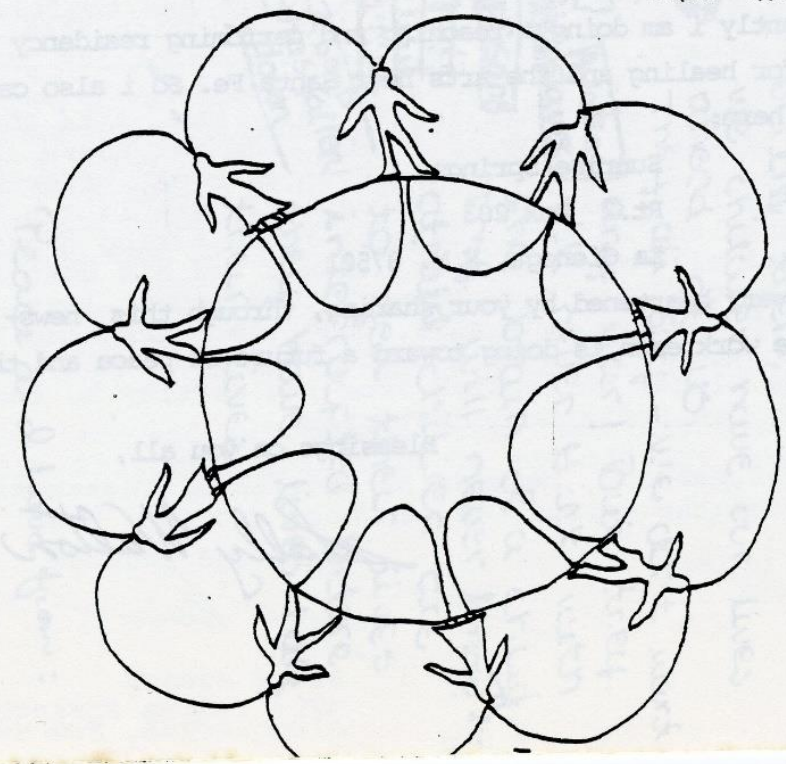

